NOAA Technical Report NMFS Circular 398

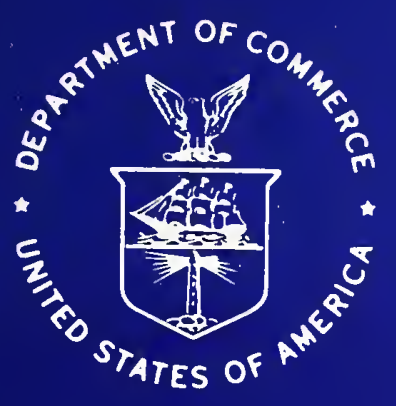

Marine Flora and Fauna of the Northeastern United States. Higher Fungi: Ascomycetes, Deuteromycetes, and Basidiomycetes

\author{
A. R. Cavaliere
}

March 1977

U.S. DEPARTMENT OF COMMERCE

National Oceanic and Atmospheric Administration National Marine Fisheries Service 


\section{National Marine Fisheries Service, Circulars}

The major responsibilities of the National Marine Fisheries Service (NMFS) are to monitor and assess the ahundance and geographic distribution of tishery resources, to understand and predict fluctuations in the quantity and distribution of these resources, and to establish levels for optimum use of the resources. NMIFS is also charged with the development and implementation of policies for managing national fishing grounds, development and enforcement of domest ic fisheries regulat ions, surveillance of foreign fishing off Inited States coastal waters, and the development and enforcement of international fishery agreements and policies. NMFS also assists the fishing industry 1 hrough market ing service and economic analysis programs, and mortgage insurance and vessel construction subsidies. It collects, analyzes, and publishes statistics on various phases of the industry.

The NOA.A Technical Report NMFS Circular series continues a series that has heen in existence since 1941. The Circulars are technical publications of general interest intended to aid conservation and management. Puhlications that review in considerable detail and at a high technical level certain broad areas of research appear in this series. Technical papers originating in economics studies and from manage ment investigations appear in the Circular series.

VOA.A Technical Report NMFS Circulars are available free in limited numbers to governmental agencies, hoth Federal and State. They are also available in exchange for other scientific and technical publications in the marine sciences. Individual copies may be obtained (unless otherwise noted) from D825. Technical Information Division, Environmental Science lnformation Center, NOAA, Washington, D.C. 20235. Recent Circulars are:

365. Processing EASTROPAC STD data and the construction of ver. tical temperaturc and salinity sections by computer. By Forrest R. Miller and Kenneth $A$. Bliss. February 1972 , iv +17 p., 8 figs., 3 app. figs. For sale by the Superintendent of Documents, U.S. Government Printing Of. fice. Washington, D.C. 20402 .

.itit. Kev to field identification of anadromous jusenile salmonids in the Pacific Northwest. By Robert J. MacConnell and George R. Snyder. January 1972, iv +6 p., 4 figs. For sale by the Superintendent of Documents, U'S. Government Printing Office, Washington, D.C. 20402.

367. Engineering economic model for fish protein concentration proceses By K. K. Almenas, L. C. Durilla, R. C. Ernst, J. W. Gentry, M. B. Hale, and J. M. Marchello. October 1972, iii +175 p., 6 figs., 6 tables. For sale by the Superintendent of Documents, U.S. Government Printing Office, Washington. D.C. 20402.

368. Cooperative Gulf of Mexico estuarine inventory and study, Florida: Phase I, area description. By J. Kneeland McNulty, William N. Lindall, Jr., and James E. Sykes. November 1972, vii + 126 p., 46 figs., 62 tables. For sale hy the Superintendent of Documents, U.S. Government Printing Office, Washington, D.C. 20402.

369. Field guide to the anglefishes (Pomacanthidae) in the western Atlantic. By Henry A. Feddern. November 1972, iii +10 p., 17 figs. For sale by the Superintendent of Documents, U.S. Government Printing Of. fice. Washington, D.C. 20402.

370. Collecting and processing data on fish eggs and larvae in the California Current region. By David Kramer, Mary J. Kalin, Elizaheth G. Stevens, James R. Thrailkill, and James R. Zweifel. November 1972, iv +38 p., 38 figs., 2 tables. For sale by the Superintendent of Documents, U.S. Government Printing Office, Washington, D.C. 20402.

371. Ocean fishery management: Discussion and research. By Adam A. Sokoloski (edilor). (17 papers, 24 authors.) April 1973, vi +173 p., 38 figs. 32 tables, 7 app. tables.

372. Fishery puhlications, calendar year 1971: Lists and indexes. By Thrmas A. Manar. Octoher 1972, iv +24 p., $1 \mathrm{fcg}$. For sale by the superintendent of Documents. U.F. Government Printing Office, Washington. D.C. 20.402 .

374. Marine flora and fauna of the northeastern United States. Annelida: Oligochaeta. By David G. Cook and Ralph O. Brinkhurst. May 197.3. iii +23 p.. 82 figs. For sale by the Superintendent of Documents, ['.S. Government Printing Office, Washington, D.C. 20402.

375. Vew Polychaeta from Beaufort, with a key to all species recorded from Nirth Carolina. By John H. Day. July 1973, xiii + 140 p., 18 figs., 1 ahle For sale hy the Superintendent of Documents, U.S. Government Prunting Office. Washington, D.C. 20402

3\%6. Hottrm-water temperatures on the continental shelf, Nova Scotia in Vew Jersey By John B Colton. Jr and Ruth R. Stoddard. June 197.3, iut $+5.5 \mathrm{p}$. 15 Tigs. 12 app. tahles. For sale hy the Superintendent of Drxuments, L.S. Grovernment Printing Office, Washington, D.C. 20402.
377. Fishery publications, calendar year 1970: Lists and indexes. By Mary Ellen Engett and Lee C. Thorson. December 1972, iv + 34 p., 1 fig. For sale hy the Superintendent of Documents, U.S. Government Printing Office, Washington, D.C. 20402.

378. Marine flora and fauna of the northeastern United States. Protozoa: Ciliophora. By Arthur C. Borror. September 1973, iii + 62 p., 5 figs. For sale hy the Superintendent of Documents, U.S. Government Printing Office. Washington, D.C. 20402.

379. Fishery publications, calendar year 1969: Lists and indexes. By Lee C. Thorson and Mary Ellen Engett. April 1973, iv + 31 p., 1 fig. For sale hy the Superintendent of Documents, U.S. Government. Printing Office, Washingt on, D.C. 20402 .

380). Fishery publications, calendar year 1968: Lists and indexes. By Mary Ellen Engett and Lee C. Thorson. May 1973, iv +24 p., 1 fig. For sale hy the Superintendent of Documents. U.S. Government Printing Office, Washington, D.C. 20402

381. Fishery publications, calendar year 1967: Lists and indexes. By Lee C. Thorson and Mary Ellen Engett. July 1973, iv +22 p., 1 fig. For sale hy the Superintendent of Documents, U.S. Government Printing Office. Washington, D.C. 20402.

382. Fishery puhlications, calendar year 1966: Lists and indexes. By Mary Ellen Engett and Lee C. Thorson. July 1973, iv +19 p., 1 fig. For sale hy the Superintendent of Documents, U.S. Government Printing Office, Washington, D.C. 20402 .

38.3. Fishery puhlications, calendar year 1965: Lists and indexes. By Lee C. Thorson and Mary Fllen Engett. Julv 1973, iv +12 p., 1 fig. For sale hy the Superintendent of Documents, U.S. Government Printing Office, Washington, D.C. 20402

384. Marine flora and fauna of the northeastern United States. Higher plants of the marine fringe. By Edwin T. Moul. September 1973, iii +60 p., 109 figs. For sale by the Siperintendent of Documents, U.S. Government Printing Office, Washington, D.C. 20402.

385. Fishery puhlications, calendar year 1972: Lists and indexes. By Lee C. Thorson and Mary Ellen Engett. Novemher 1973, iv +23 p., 1 fig. For sale hy the Superintendent of Documents, U.S. Government Printing Of. fice, Washington, D.C. 20402.

386. Marine flora and fauna of the northeastern United States. Pycnogonida. By Lawrence R. Mcr'loskey. Septemher 1973, iii + 12 p., 1 fig. for sale hy the Superintendent of Documents, U.S. Government Printing (Office, Washington, D).C. 20402.

387. Marine flora and fauna of the northeastern United States. Cruslacea: Stomatopoda. By Raymond B. Manning. Fehruary 1974, iii + 6 p., 10 figs. For sale by the Superintendent of Documents, U.S. Govern. ment Printing (office, Washington, D.C. 20402. 
NOAA Technical Report NMFS Circular 398

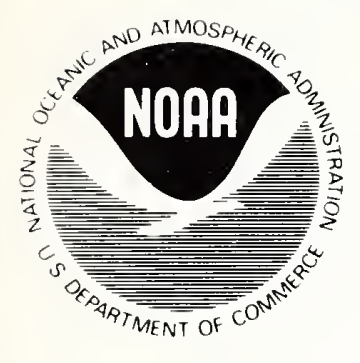
Marine Flora and Fauna of the Northeastern United States Higher Fungi: Ascomycetes, Deuteromycetes, and Basidiomycetes

\author{
A. R. Cavaliere
}

March 1977

U.S. DEPARTMENT OF COMMERCE

Juanita M. Kreps, Secretary

National Oceanic and Atmospheric Administration Robert M. White, Administrator

National Marine Fisheries Service

Robert W. Schoning, Director 


\section{FOREWORD}

This issue of the "Circulars" is part of a subseries entitled "Marine Flora and Fauna of the Cortheastern United States." This subseries will consist of original, illustrated, modern manuals on the identification. classification, and general biology of the estuarine and coastal marine plants and animals of the Northeastern United States. Manuals will be published at irregular intervals on as many taxa of the region as there are specialists available to collaborate in their preparation.

The manuals are an outgrowth of the widely used "Keys to Marine Invertebrates of the Woods Hole Region," edited by R. I. Smith. published in 1964, and produced under the auspices of the Systematics-Ecology Program, Marine Biological Laboratory, Woods Hole, Mass. Instead of revising the "Woods Hole Kess," the staff of the Systematics-Ecology Program decided to expand the geographic coverage and bathymetric range and produce the keys in an entirely new set of expanded publications.

The "Marine Flora and Fauna of the Northeastern United States" is being prepared in collaboration with systematic specialists in the United States and abroad. Each manual will be based primarily on recent and ongoing revisionary systematic research and a fresh examination of the plants and animals. Each major taxon, treated in a separate manual, will include an introduction, illustrated glossary, uniform originally illustrated keys, annotated check list with information when available on distribution, habitat, life history, and related biology, references to the major literature of the group, and a systematic index.

These manuals are intended for use by biology students, biologists, biological oceanographers, informed laymen, and others wishing to identify coastal organisms for this region. In many instances the manuals will serve as a guide to additional information about the species or the group.

Geographic coverage of the "Marine Flora and Fauna of the Northeastern United States" is planned to include organisms from the headwaters of estuaries seaward to approximately the $200 \mathrm{~m}$ depth on the continental shelf from Maine to Virginia, but may vary somewhat with each major taxon and the interests of collaborators. Whenever possible representative specimens dealt with in the manuals will be deposited in the reference collections of major museums.

After a sufficient number of manuals of related taxonomic groups have been published, the manuals will be revised, grouped, and issued as special volumes. These volumes will thus consist of compilations of individual manuals within phyla such as the Coelenterata, Arthropoda, and Mollusca, or of groups of phyla. 


\section{CONTENTS}

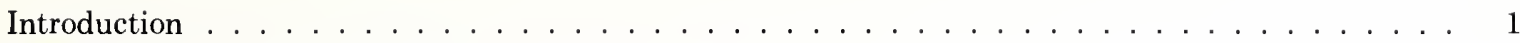

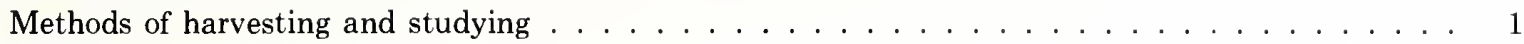

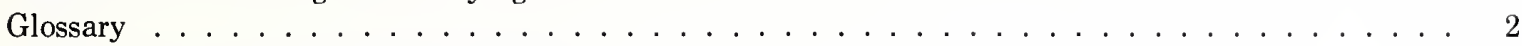

Figures of reproductive structures and spore shapes . . . . . . . . . . . . . . . 4

Key to major groups of fungi occurring in the marine environment . . . . . . . . . . . . . 8

Key to spore groups of Ascomycetes . . . . . . . . . . . . . . . . . . . . . . . 11

Key to genera and species of Scolecosporae . . . . . . . . . . . . . . . . . . . . 12

Key to species of Lindra . . . . . . . . . . . . . . . . . . . . . . . . . . . . . . . . 14

Key to genera and species of Amerosporae . . . . . . . . . . . . . . . . . . . . 14

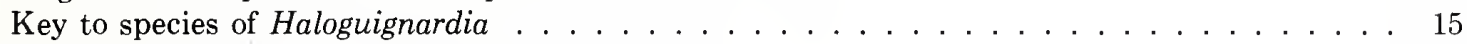

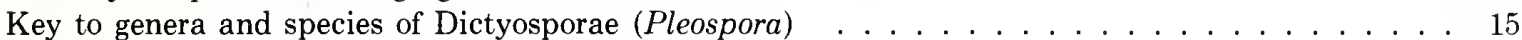

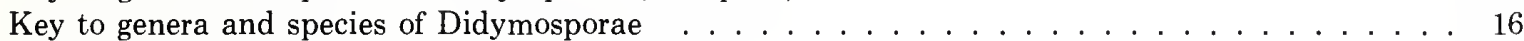

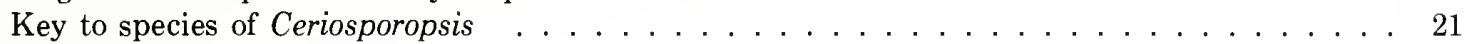

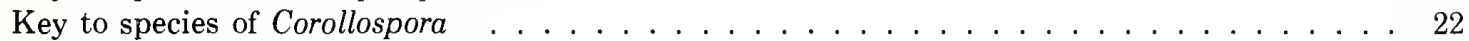

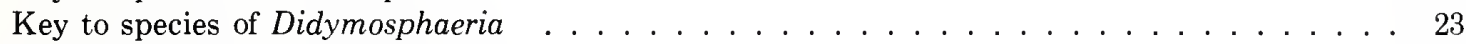

Key to species of Halosphaeria . . . . . . . . . . . . . . . . . . . . . . . . . 23

Key to genera and species of Phragmosporae . . . . . . . . . . . . . . . . . . . . . 27

Key to species of Haligena . . . . . . . . . . . . . . . . . . . . . . . . . . . . . 29

Key to species of Leptosphaeria . . . . . . . . . . . . . . . . . . . . . . . . . . . . . . . . . . . . 29

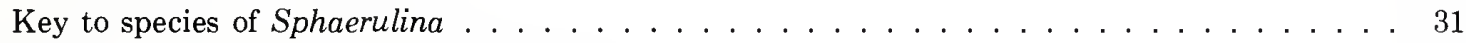

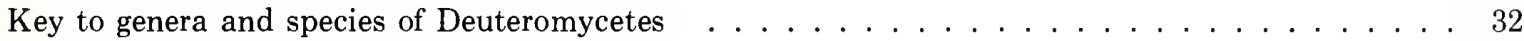

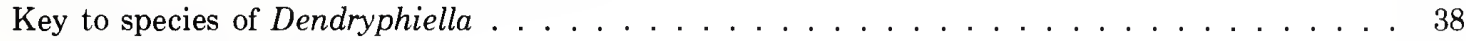

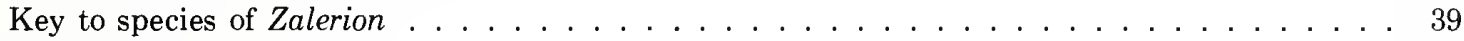

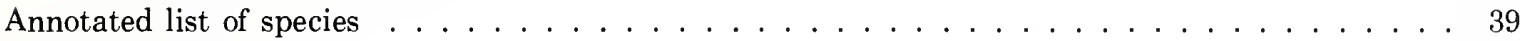

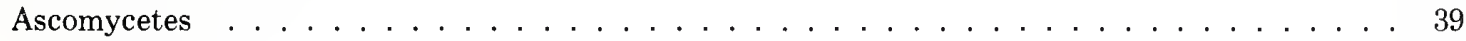

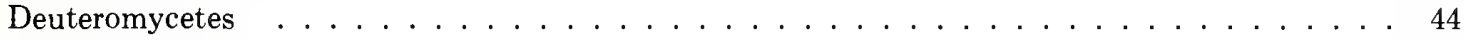

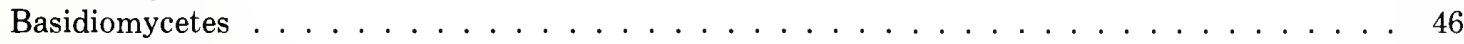

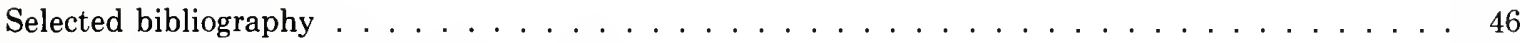

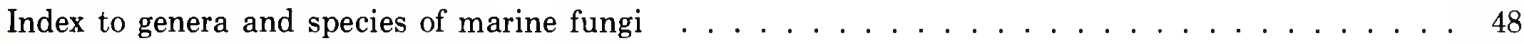

Acknowledgments . . . . . . . . . . . . . . . . . . . . . . . . . . . . 49

Coordinating Editor's comments . . . . . . . . . . . . . . . . . . . . 49 
Digitized by the Internet Archive in 2013 


\title{
Marine Flora and Fauna of the Northeastern United States. Higher Fungi: Ascomycetes, Deuteromycetes, and Basidiomycetes
}

\author{
A. R. CAVALIERE ${ }^{1}$
}

\begin{abstract}
This manual provides an illustrated key and alphabetical listing, with brief descriptions, of common genera of higher marine fungi in the classes Ascomycetes, Deuteromycetes (Fungi Imperfecti), and a single member of the Basidiomycetes. A glossary and selected bibliography complement the key. Information on methods of harvesting, incubation, and studying these fungi is also included.
\end{abstract}

\section{INTRODUCTION}

This manual is a guide to the genera of higher marine fungi that inhabit the intertidal zone of the Atlantic waters extending from North Carolina to Nova Scotia. Keys, descriptions, and illustrations are included for genera of Ascomycetes, Deuteromycetes (Fungi Imperfecti), and a single member of the Basidiomycetes. Less conspicuous saline forms of zoosporic fungi, the socalled marine Phycomycetes, as well as parasitic fungi, amoeboid forms, and those inhabiting the intestinal tract of arthropods, are not included in this account. In addition, species of higher fungi are excluded which have been reported only once or are rare or inconspicuous in the mycological flora.

Fungi inhabiting the saline environment appear to be cosmopolitan in distribution with only a few species hav. ing been shown to be endemic to one particular region. Some members of the marine mycoflora which are tropical, however, tend to be associated only with mangrove communities or other phanerogams which are restricted to warmer waters.

\section{METHODS OF HARVESTING AND STUDYING}

Marine Ascomycetes, Basidiomycetes, and Fungi Imperfecti occur as saprophytes on driftwood, cordage, and other cellulosic material, or as weak parasites infesting dying species of marine phanerogams or algae. Various plant parts, grass culms, driftwood, and algae are best collected along the shore at low tide and kept submerged in a container of seawater until studied. Fungi may also be induced to grow on substrates introduced into the seawater. A $1 / 4$-inch hole is drilled through the center of small, $4 \times 6$ inch panels of various

'Department of Biology, Gettysburg College, Gettysburg, PA 17325. kinds of wood. These are then attached, in linear fashion, to a knotted, polyethylene or nylon line and submerged at or below the low tide limit for a $2-4$ mo period. When panels are harvested, they are scraped of all macroscopic fouling organisms and rinsed in seawater. They are then examined for fungal growth and/or incubated individually for an additional period of one to several months in sterile, dry, air-tight aquaria or other glass containers. Several methods of harvesting and incubating lignicolous fungi are described in the literature.

Ascocarps, dense mycelial growth as well as conidial clusters, are located with a dissecting scope utilizing a high intensity light source. Conidial heads may also be located by placing thin strips of substrate in a drop of seawater on a slide and observing the preparation directly under a compound microscope. Semipermanent mounts are made by placing fruiting structures into a drop of lactophenol ( $20 \mathrm{~g}$ phenol crystals; $20 \mathrm{~g}$ lactic acid; $40 \mathrm{~g}$ glycerol; $20 \mathrm{~g}$ distilled water; $0.01 \mathrm{~g}$ cotton blue or acid fuchsin) or Hoyer's medium (made by soaking $30 \mathrm{~g}$ of flake gum arabic in $50 \mathrm{ml}$ of distilled water for $24 \mathrm{~h}$, dissolving $200 \mathrm{~g}$ of chloral hydrate into the mixture, and then stirring in $20 \mathrm{ml}$ of glycerol. Allow the mixture to settle before using.) When examining ascocarps or pycnidial structures, it is best to crush the fruiting bodies to expose the centrum. This is best accomplished by lightly tapping the cover slip with the handle end of a dissecting needle or the eraser end of a pencil. Spores of several of the marine species have gelatinous appendages which are best observed in a seawater mount under reduced light intensity or by phase contrast microscopy. Gelatinous appendages are deliquescent in most cases, short-lived, and, unfortunately, not retained satisfactorily in any known mounting medium.

Pure cultures of marine Ascomycetes and Fungi Imperfecti are initiated by introducing spores or centrum cells from several ascocarps onto low nutrient level, seawater agar media and incubating at room temperature. Kirk (1969) offers the most useful account 
of the isolation and culture of lignicolous marine fungi (0.1\% glucose; $0.01 \%$ yeast extract: $1.8 \%$ agar in aged seawater adjusted to approximately $20 \%$ \% $0.03 \%$ U.S.P. streptomycin sulfate). White birch applicator sticks, balsa strips. filter paper, or toweling paper added to the culture tubes serve as an additional cellulosic substrate. Methods of preparing specimens for embedding, serial sectioning. and differential staining are outlined elsewhere (Cavaliere 1966, 1973).

Several additional works covering various aspects of the biology and taxonomy of marine Ascomycetes may be useful to the student (Barghoorn and Linder 1944; Johnson and Sparrow 1961; Cavaliere and Johnson 1966; Kohlmever and Kohlmever 1971).

\section{GLOSSARY}

The use of mycological terminology has been reduced to a minimum. Several terms are defined as well as illustrated. More complete definitions are found in Snell and Dick (1957) and Ainsworth and Bisby (1971).

Acuminate Gradually narrowing to a point.

Amerospore One-celled spore; spore without partitions.

Amorphous Without definite shape or structure.

Anastomose To form a network of interconnecting hyphae.

Antepenultimate Refers to the third to the last cell in any row of cells.

A piculate Having one to many sharp points or denticles.

Appendage A process of any kind; a structure which adheres.

Ascocarp A fructification in Ascomycetes bearing asci and ascospores (see Figs. 1-3).

Ascospore A spore, typical of the sexual stage or cycle in Ascomycetes, borne in an ascus.

Ascus A reproductive cell in Ascomycetes; a structure, within which are produced, by meiosis, normally $4-8$ haploid spores (see Figs. 6, 7).

Attenuate Gradually narrowing or thinning.

Awl-shaped Gradually tapering from the base to a sharp, flexible or semirigid point.

Bacilliform Refers to spores which are rod-shaped (see Fig. 24).

Basidiocarp A fructification in Basidiomycetes producing basidia and basidiospores.

Basidiospore A sexual spore; produced by meiosis and borne on a basidium.

Basidium A cell within which nuclei first undergo reduction division then pass onto extensions externally forming basidiospores.

Bitunicate Refers to asci having two walls; doublelayered (see Fig. 7).

Biturbinate Refers to 2-celled spores having both ends conical and slightly curved.

Catenulate Attached in chains.

Clavate Club-shaped or thickened at the apex (see Fig. 13).

Cleistothecium A more or less spherical covering en- closing asci; a fruiting structure in the Ascomycetes (Plectomycetes) produced as a result of sexual reproduction and opening at maturity by a rupture (see Fig. 1).

Concolorous Refers to the pigmentation being the same color throughout.

Conidiophore A specialized hypha or cell bearing conidia.

Conidium Spores produced by the Deuteromycetes; a spore borne on or in a specialized hypha termed a conidiophore; asexually produced spores.

Deciduous Short-lived; falling away; not persistent.

Deliquescent Dissolving or liquifying.

Denticulate Having small teeth.

Dictyospore A spore with many transverse and longitudinal septations; a muriform spore (see Fig. 23).

Didymospore Two-celled spores; spores with a single partition.

Echinulate With minute spines.

Ellipsoidal Refers to spores having the shape of an ellipse; generally rounded at both ends and having curved sides (see Fig. 19).

Elongate Longer than broad, having parallel sides (see Fig. 18).

Endogenous Borne or developing within.

Epispore The outer layer of the spore wall.

Erumpent Breaking through the surface of the substrate; refers to the position of the fruiting body with relationship to the substrate.

Eucarpic Refers to a condition in which only part of the somatic thallus is converted in the formation of fructifications.

Filiform Refers to spores which are slender and threadlike (see Fig. 22).

Fuscous Drab, gray or smokey in color.

Fusiform Spindle-shaped or tapering at both ends (see Fig. 12).

Fusoid Somewhat fusiform.

Globose Refers to spores which are spherical (see Fig. 8).

Guttule Oily, spherical globule.

Helicospore A spiral or helicoid spore (see Fig. 20).

Holocarpic Refers to a condition in which the entire somatic thallus is converted into a fructification.

Hyaline Transparent or translucent, colorless.

Inequilateral Having unequal sides.

Innate Occurring below the surface of the substrate. Refers to the position of the fruiting body with relationship to the substrate.

Intercalary Borne or developed between the base and apex of hyphae.

Involuted Rolled or enrolled.

Lenticular Refers to spores shaped like a double convex lens (see Fig. 11).

Muriform Refers to spores having both transverse and longitudinal septations (see Fig. 23).

Oblong Longer than broad with approximately parallel sides (see Fig. 15).

Obpyriform Reverse pear-shaped (see Fig. 17).

Obtuse Blunt or rounded, not pointed. 
Ovoid Egg-shaped (see Fig. 10).

Pedicellate Borne on a pedicel or stalk.

Penultimate Refers to the next to the last cell in any row of cells.

Perithecium A more or less flask-shaped, papillate or beaked covering enclosing asci; a fruiting structure in the Ascomycetes (Pyrenomycetes) produced as a result of sexual reproduction (see Fig. 2).

Peritrichous Having flagellumlike hairs surrounding the structure.

Phialide Specialized conidiophore or cell within which conidia are produced and released (see Fig. 5).

Phragmospore A spore having two or more transverse septations.

Pleomorphic Having more than one form; polymorphic. Polymorphic Occurring in several forms.

Pseudothecium A unilocular stroma. A cavity or locule formed by the dissolution of stromatic tissue (see Fig. 3).

Pycnidium In Deuteromycetes, a more or less flaskshaped structure bearing conidia on conidiophores internally (see Fig. 4).

Pyriform Pear-shaped (see Fig. 16).
Rhomboidal Refers to spores having oblique angles and equal or unequal adjacent sides; more or less diamondshaped.

Scolecospore A long, thread-shaped, filiform or vermicular spore (see Fig. 22).

Septate Having crosswalls or partitions.

Sessile Without a pedicel or stalk.

Seta Slender, bristle-shaped structure.

Sheath A covering or envelope.

Staurospore A spore which is more or less star-shaped (see Fig. 21).

Stroma A more or less tightly interwoven mass of hyphae within or on which reproductive structures are formed.

Subglobose Refers to spores or ascocarps which are nearly spherical; sides slightly flattened or compressed from the top (see Fig. 9).

Truncate Ending abruptly, squared off at the apex.

Undulant Wavy sheath or covering.

Unitunicate Refers to asci having a single wall (see Fig. $6)$.

Verrucose Covered with warts or marks.

Verruculose Covered with minute warts. 


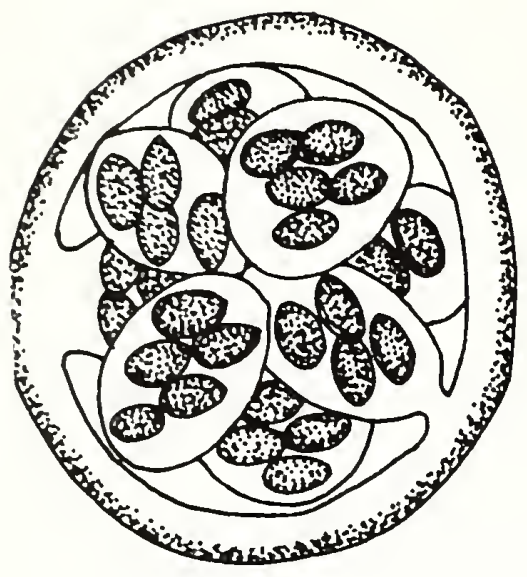

1. cleistothecium

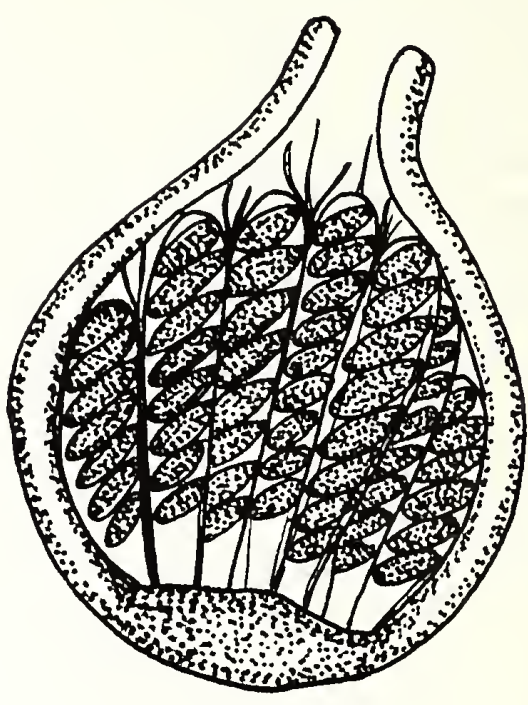

2. perithecium

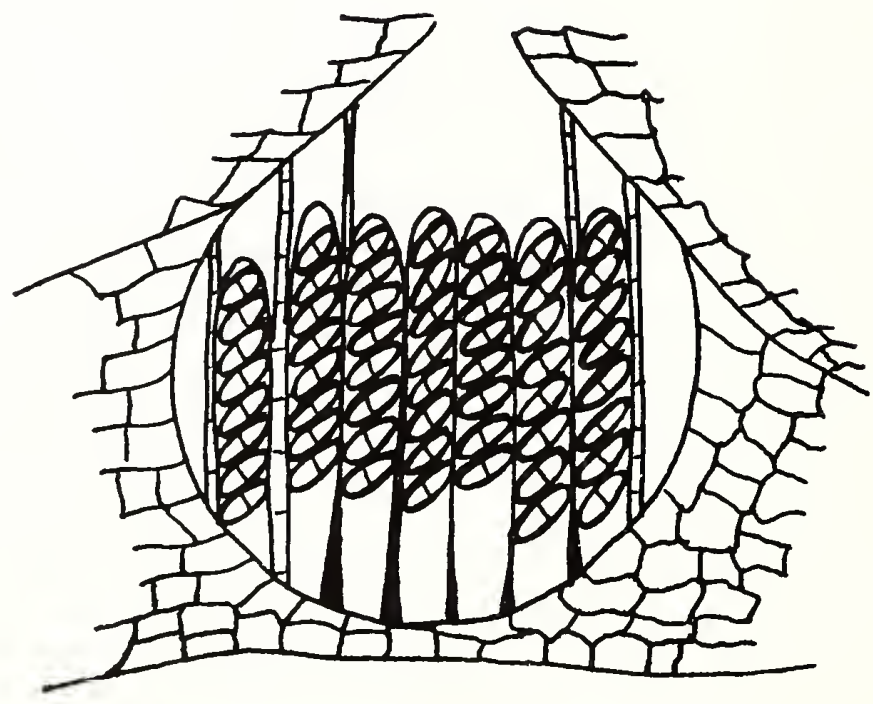

3. pseudothecium

Figures 1-3.- Reproductive structures in Ascomycetes. 


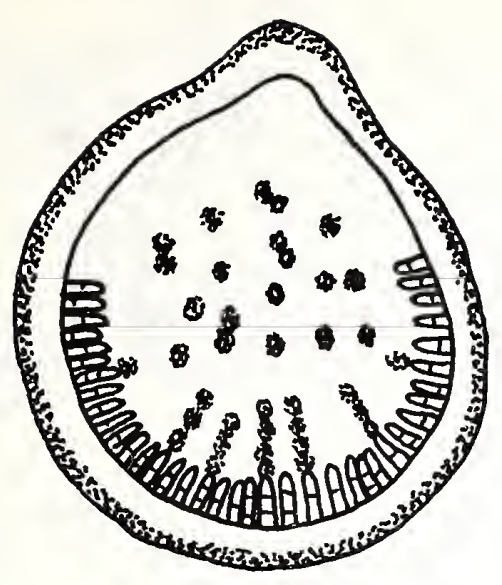

4. pycnidium

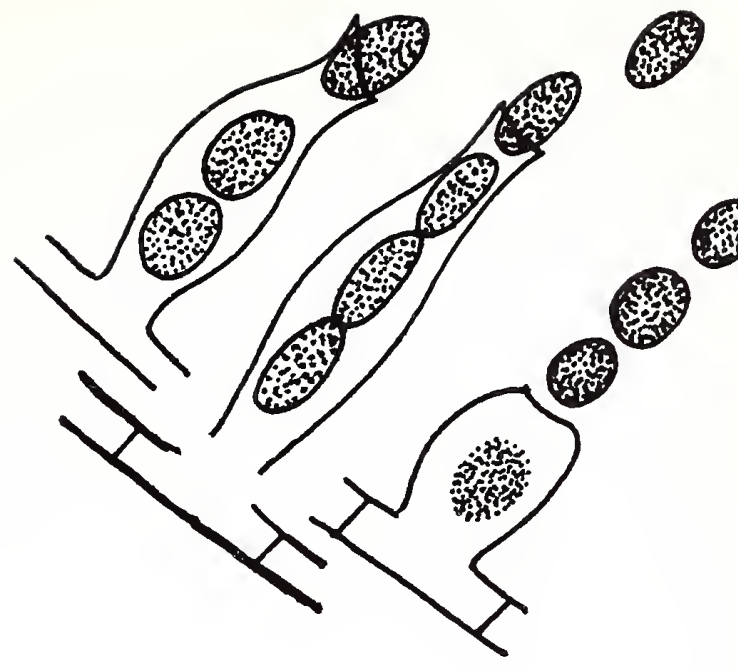

5. phialide

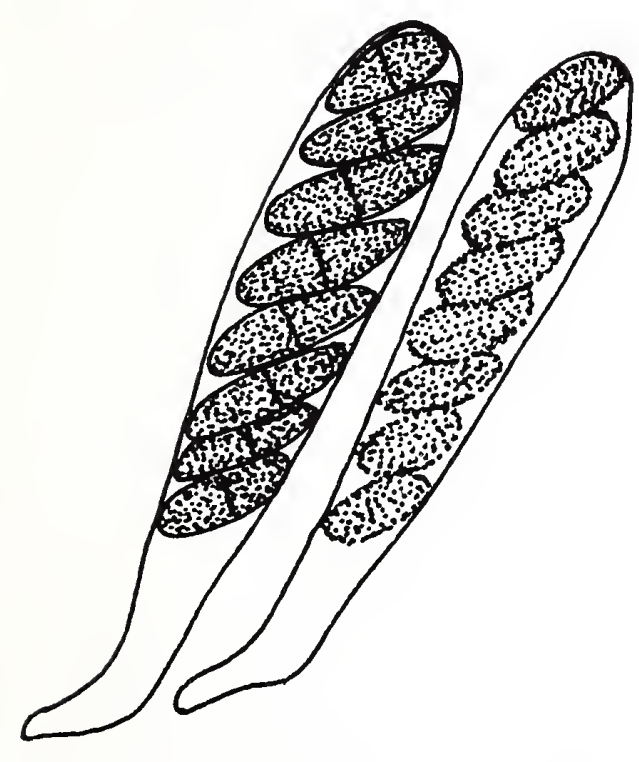

6. unitunicate asci

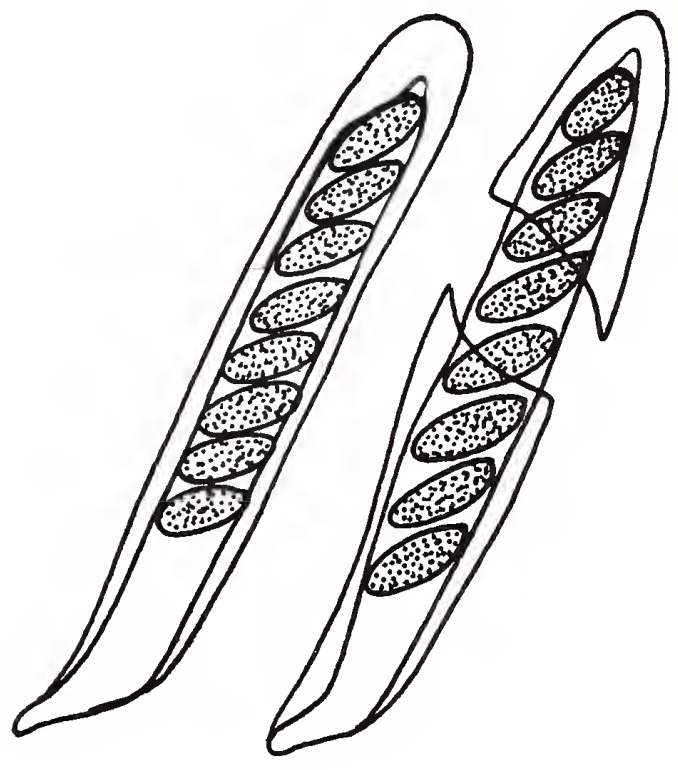

7. bitunicate asci

Figures 4-7.-Reproductive structures in Ascomycetes and Deuteromycetes. 


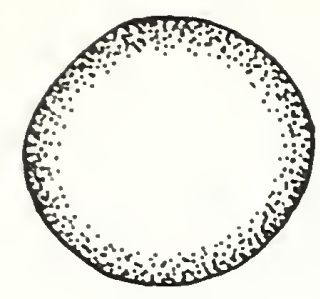

8. globose

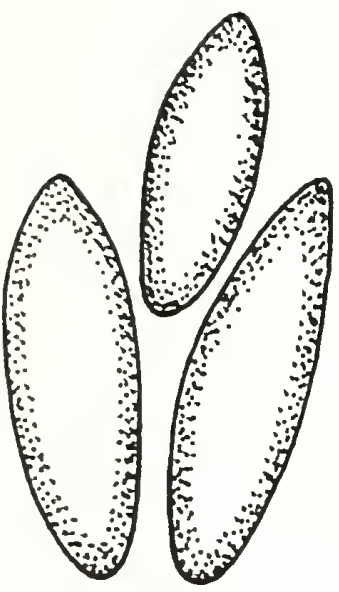

11. lenticular

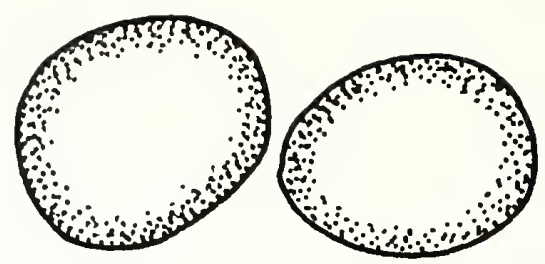

9. subglobose

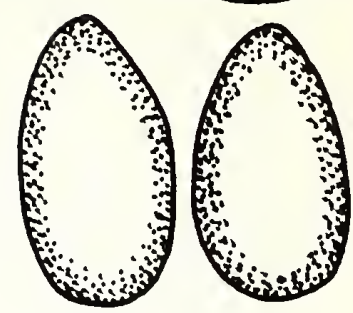

10. ovoid

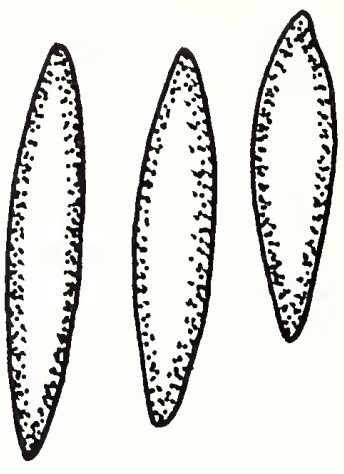

12. fusiform

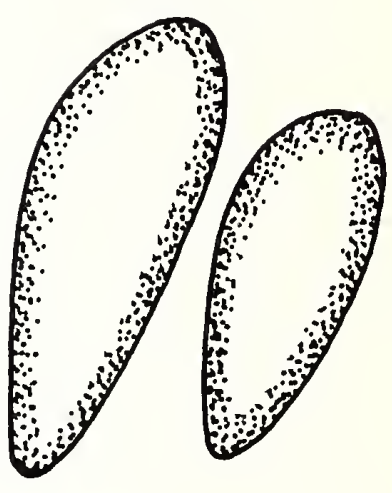

13. clavate

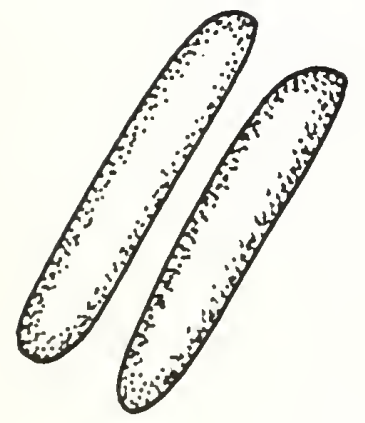

14. cylindrical

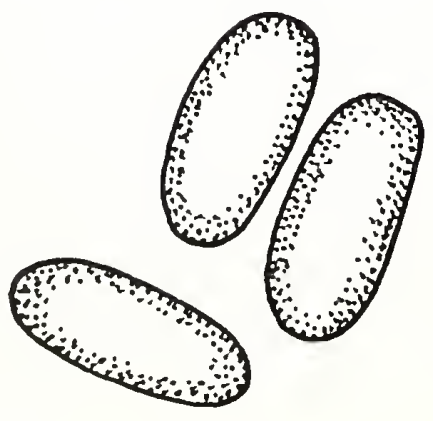

15. oblong

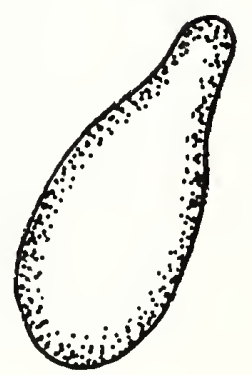

16. pyriform

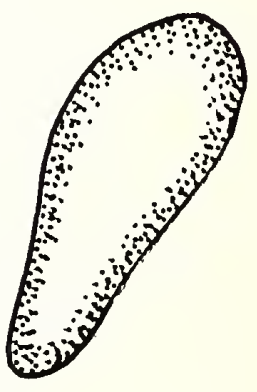

17. obpyriform 


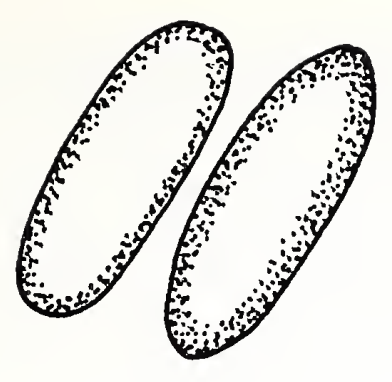

18. elongate

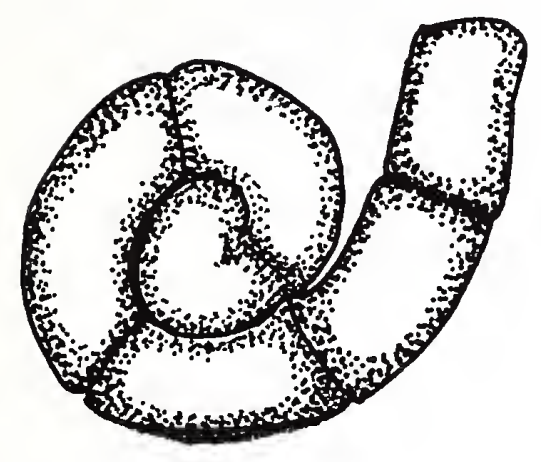

20. helicoid

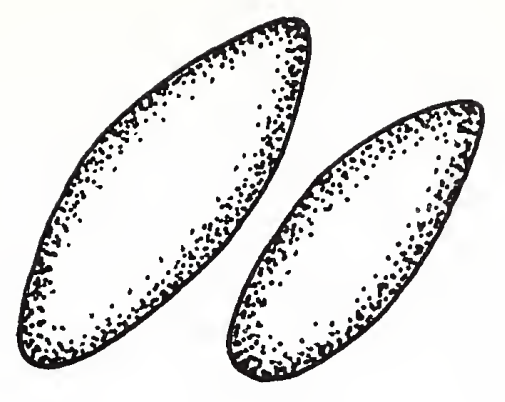

19. ellipsoidal

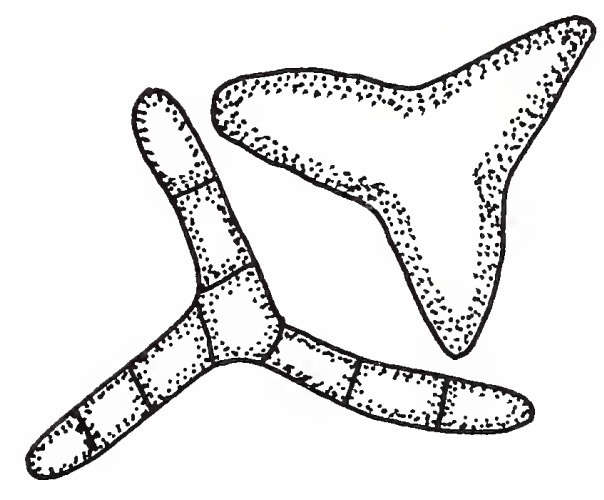

21. staurospore

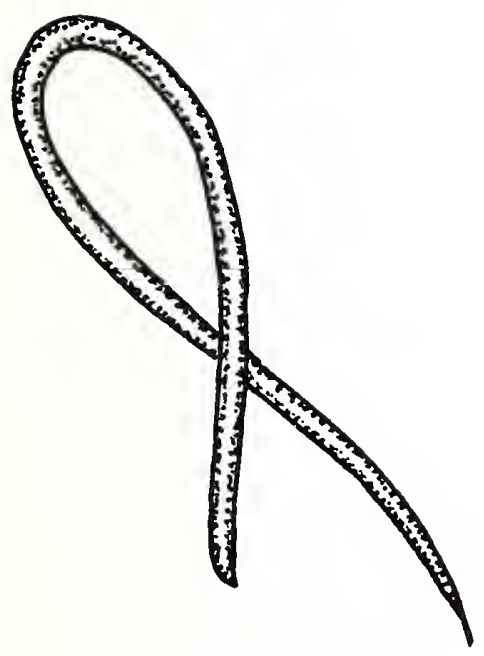

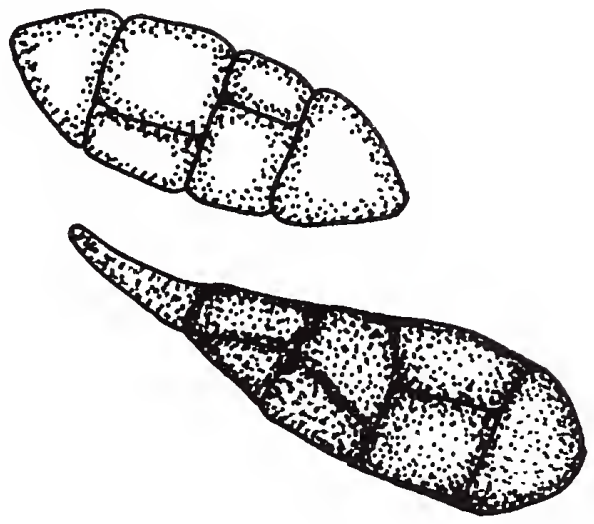

23. muriform

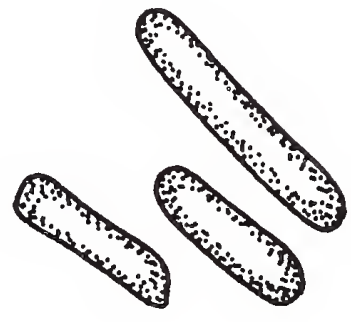

24. bacilliform

Figures 18-24.-Spore shapes in fungi. 
The preliminary key separates the nine major groups of fungi occurring in the marine environment: Labyrinthulae. Chytridiomycetes. Hyphochytridiomycetes. Plasmodiophoromycetes. Oomycetes. Trichomycetes. Deuteromycetes. Ascomycetes, and Basidiomycetes (Nia librissa, the only representative of the Basidionycetes included in this treatment, is keyed out directly). Both the classes Ascomycetes and Deuteromycetes are separated into genera utilizing the Saccardo sporological system. Morphology and color of the spores and conidia are the essential features employed in the Saccardo system. While the Deuteromycetes are keyed directly to genera or species, the Ascomycetes are divided into spore groups (Amerosporae, Dictyosporae, Didymosporae, Phragmosporae, Scolecosporae). Each spore group is then separated into the various genera. Genera of Ascomycetes are finally delimited into species based primarily on spore size and on the nature of spore appendages in those species possessing them.

1 Vegetative phase or stage entirely amoeboid

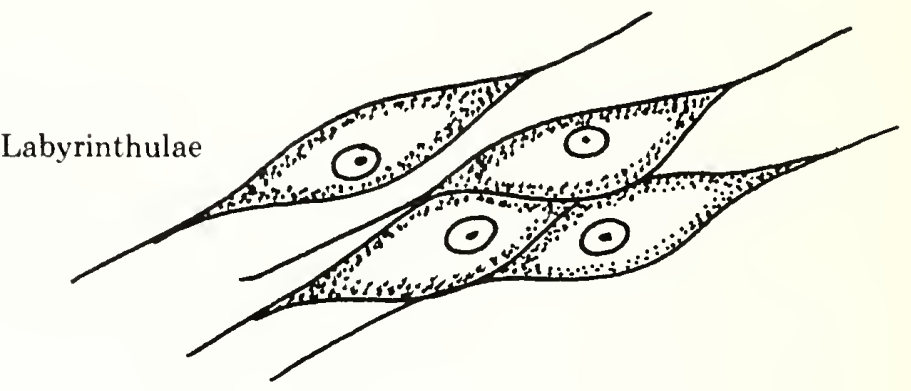

2 (1) Flagellated cells present ............. . .

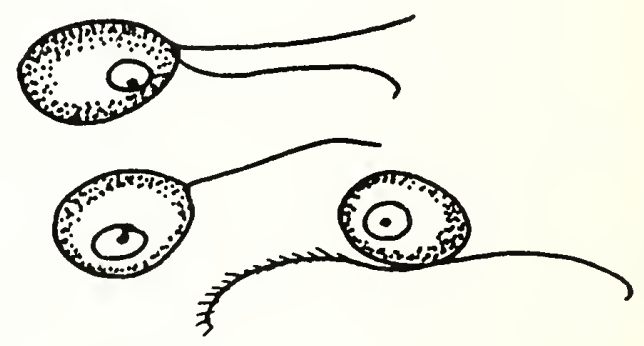

2 (1) Flagellated cells lacking

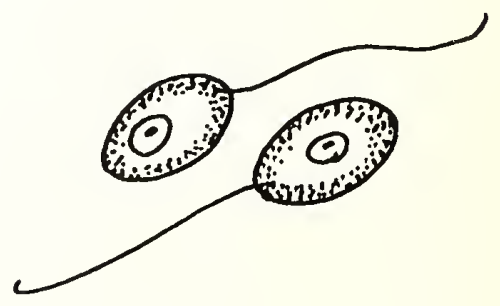


3 (2) Motile cells biflagellate ............. 5

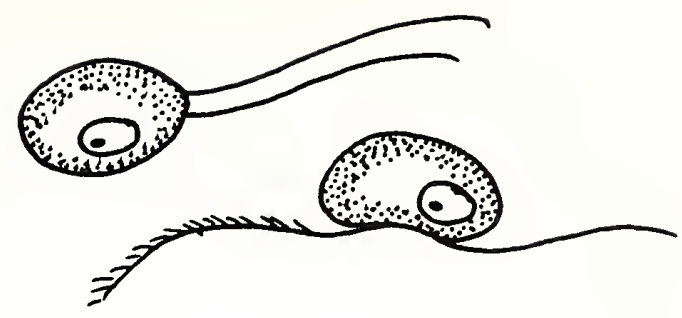

4 (3) Flagellum of the whiplash type, posteriorly inserted ..

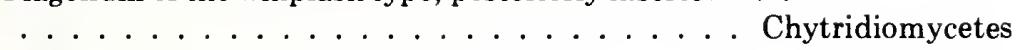

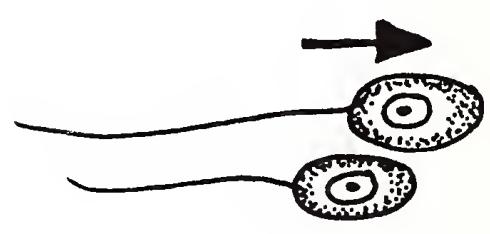

4 (3) Flagellum of the tinsel type, anteriorly inserted .... Hyphochytridiomycetes

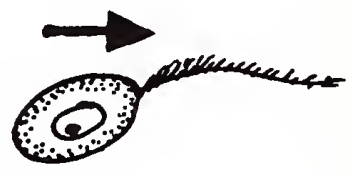

5 (3) Flagella heterokont, both of the whiplash type .....Plasmodiophoromycetes

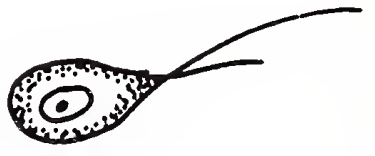

5 (3) Flagella nearly isokont, one of the whiplash type, the other tinsel $\ldots \ldots \ldots \ldots \ldots$ Oomycetes

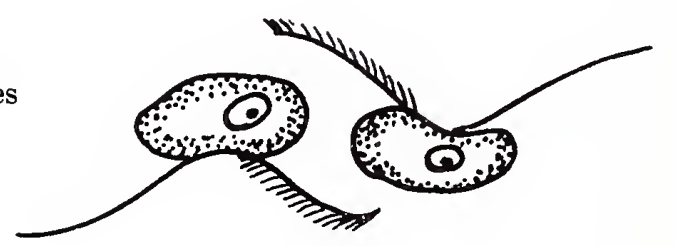


(i) (2) Hyphae attached to the digestive tract or cuticle of arthropods .............. Trichomycetes

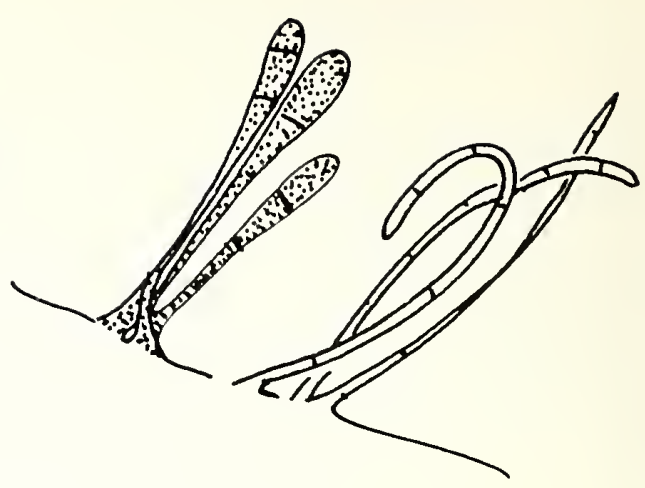

6 (2) Hyphae saprobic or parasitic on algae, phanerogams or other cellulosic materials . . . . . . . 7

(6) Sexually formed spores lacking; conidia usually formed in pycnidia (Fig. 4) or directly on vegetative hyphae . . . . Deuteromycetes (p. 32)

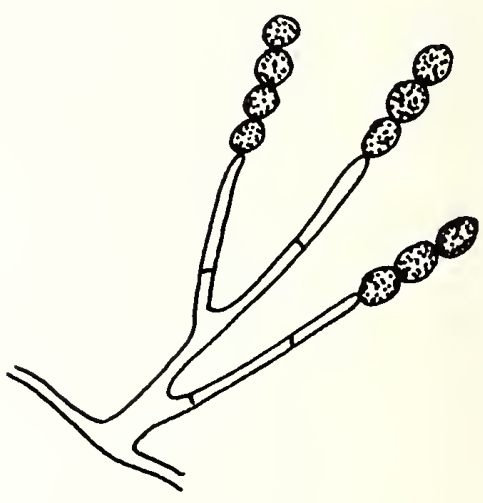

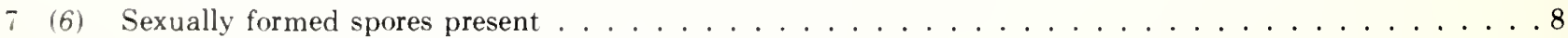

8 (7) Sexual spores, usually 8 in number, produced endogenously

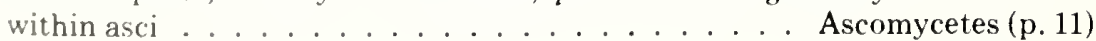

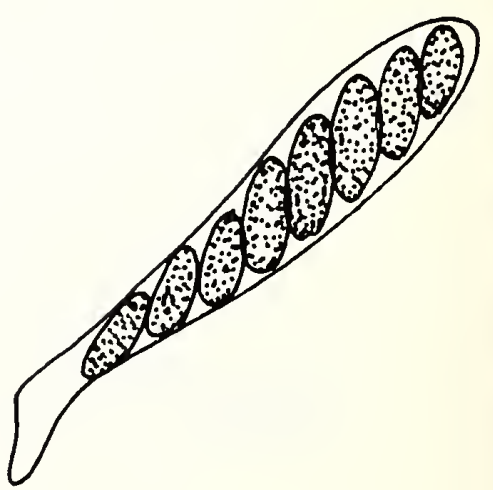


8 (7) Sexual spores, usually $2-4$ in number, exogenously produced on basidia . .

. . . . . . Basidiomycetes (Nia vibrissa p. 46)
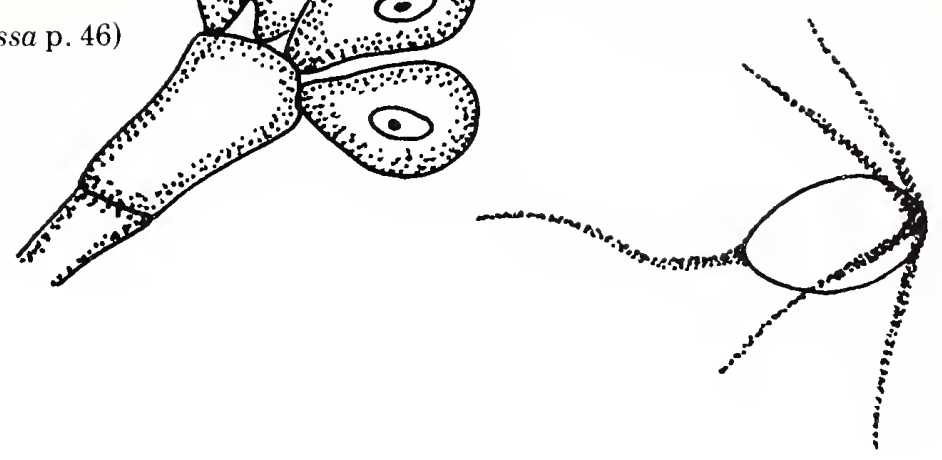

KEY TO SPORE GROUPS OF ASCOMYCETES

1 Ascospores filiform or slender; more than 10 times as

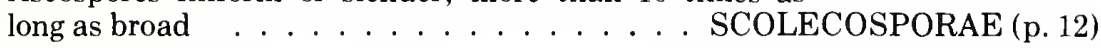

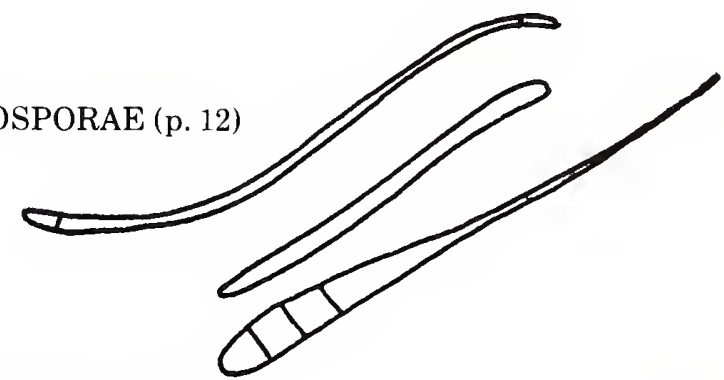

2 (1) Ascospores single-celled (nonseptate) . . . . . AMEROSPORAE (p. 14)

2 (1) Ascospores two- or more-celled (septate) . . . . . . . . . 3

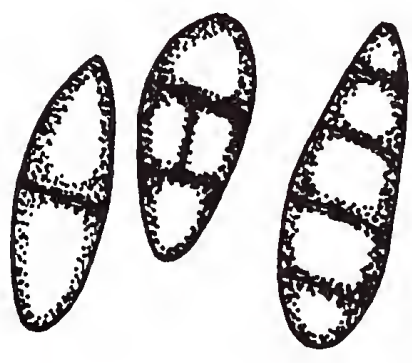


3 (2) Ascospores with transverse and longitudinal septations; muriform .

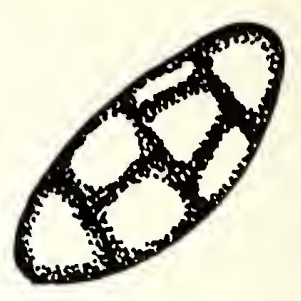

4 (3) Ascospores three- or more-celled (multiseptations) ........

\section{KEY TO GENERA AND SPECIES OF SCOLECOSPORAE}
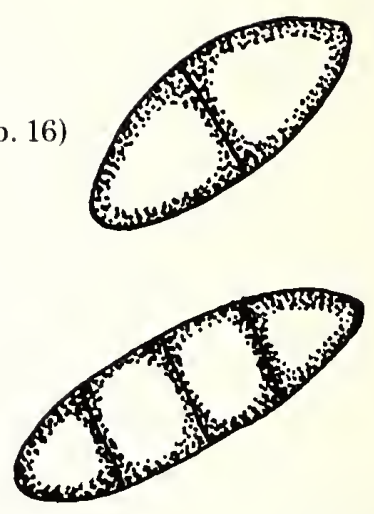

2 (1) Ascospores 50-750 $\mu$; provided with a conoid cell or appendage at each end Lulworthia medusa

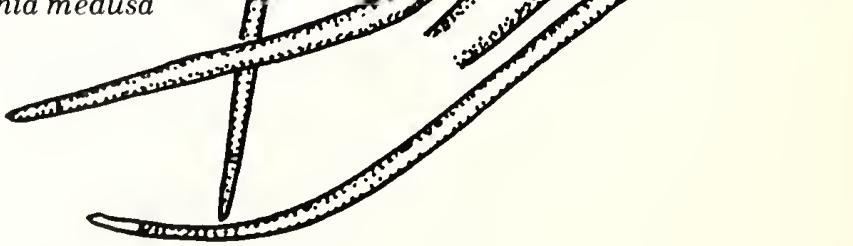


2 (1) Ascospores usually shorter than $30 \mu$; without append-

ages ... (see also Amerosporae) . . . . . . . Halonectria milfordensis

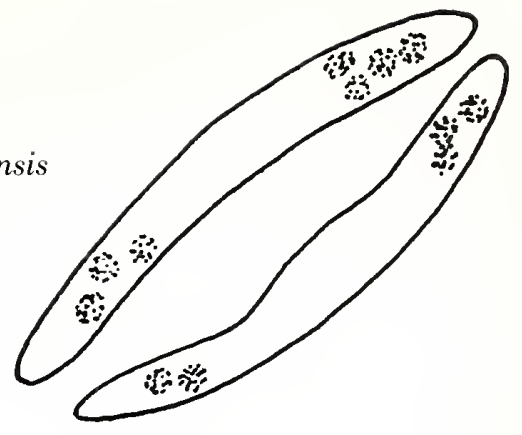

3 (1) Ascospores with a caplike, bulbous or threadlike appendage at each end . . . . . . . . . . . . . 4

3 (1) Ascospores without appendages $\ldots \ldots \ldots \ldots$

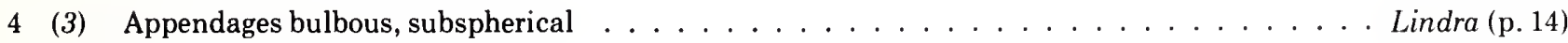

4 (3) Appendages caplike or threadlike . . (see also Phragmosporae) . . . . . . . . . . . . Haligena (p. 29)

5 (3) Ascospores to $100 \mu \mathrm{long}, 3$ - to 4-celled, tapering at one end .......................... ascophylli

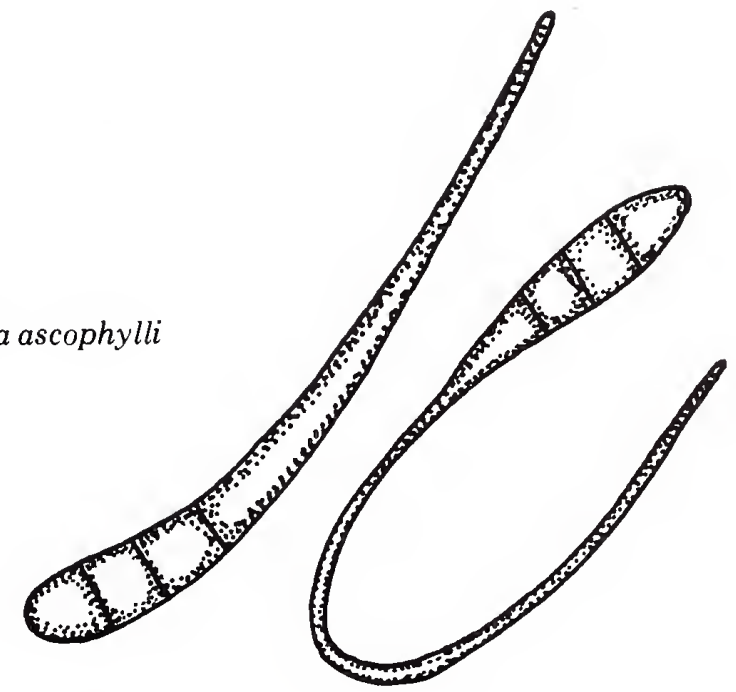

5 (3) Ascospores to $400 \mu$ long, filiform, cylindrical or tapering at both ends . . . . . . . . . . Lindra (p. 14) 
Key to Species of Lindra

Ascospores 15 - to 19-celled, tips slightly inflated ..... L. thalassiae

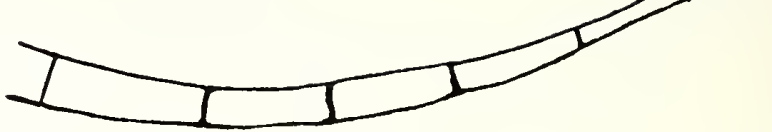

Ascospores 28- to 52-celled, tips provided with a globose appendage .L. inflata

\section{KEY TO GENERA AND SPECIES OF AMEROSPORAE}

1 Ascospores with several rigid, awl-shaped appendages arising from several positions along the spore wall .

Amylocarpus encephaloides

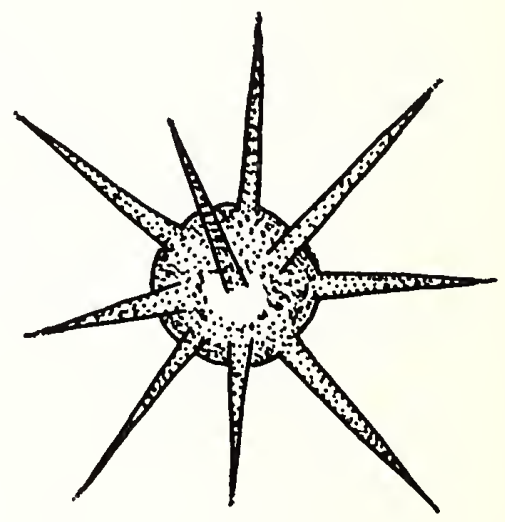

2 (1) Ascospores many times longer than broad, fusiform or cylindrical, straight or curved... (see also Scolecosporae

Halonectria milfordensis

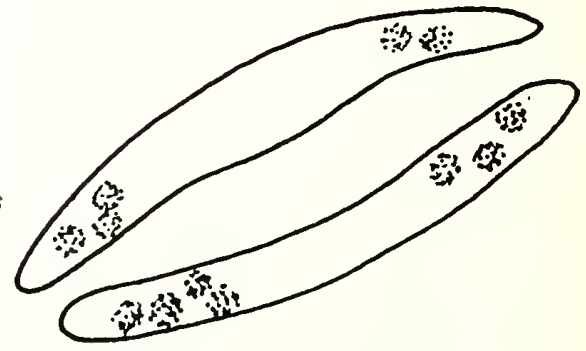


2 (1) Ascospores more or less ellipsoidal, not many times longer than broad

\section{Key to Species of Haloguignardia}
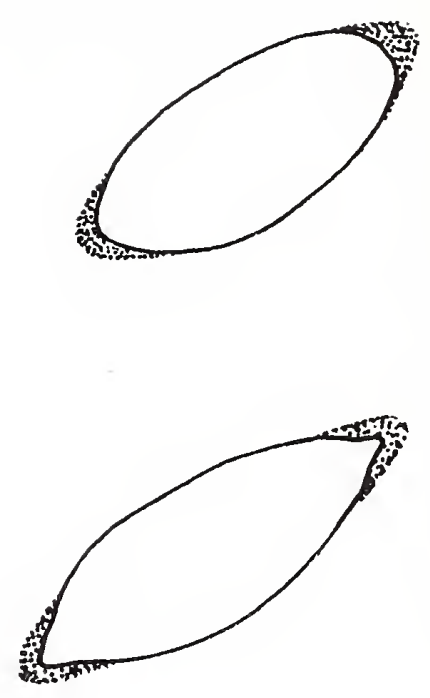

\section{KEY TO GENERA AND SPECIES OF DICTYOSPORAE (PLEOSPORA)}

Ascospores more than $35 \mu$ long, 7-9 transverse septa . . . . . . . . Pleospora pelagica

Ascospores less than $35 \mu$ long, 3-7 transverse septa ........... Pleospora pelvetiae

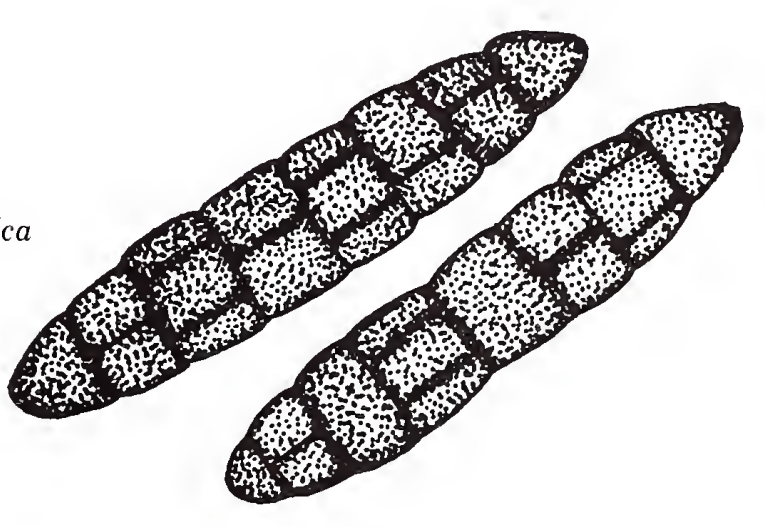




\section{KEY TO GENERA AND SPECIES OF DIDYMOSPORAE}

1 Ascospores surrounded by a gelatinous sheath and/or provided with appendages

.11

2 (1) Ascospores hyaline

3

(I) Ascospores yellow, yellow-brown, brown, or dark brown

3 (2) Ascocarp a pseudothecium containing bitunicate asci $\ldots \ldots \ldots \ldots$

3 (2) Ascocarp a perithecium containing unitunicate asci $\ldots \ldots \ldots$

4 (3) Ascospores ellipsoidal, inequilateral . . . . Didymella fucicola

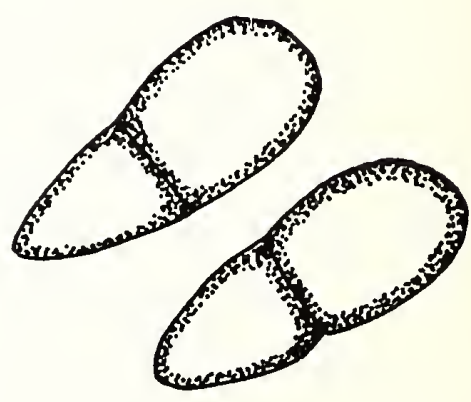

4 (3) Ascospores fusiform to oblong, equilateral

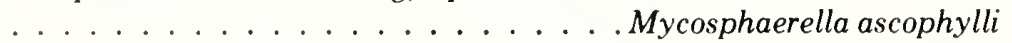

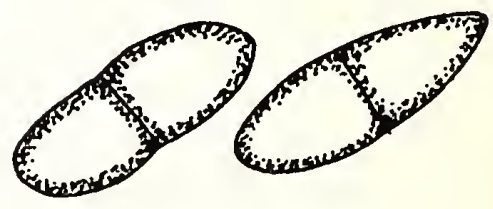

5 (3) Ascospores fusiform to ellipsoidal, never more than $10 \mu$

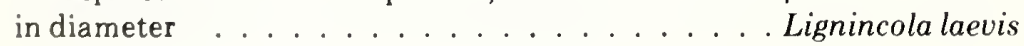

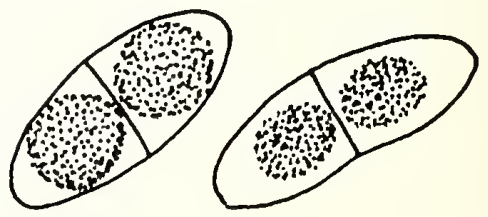


5 (3) Ascospores broadly ellipsoidal or ovoid; $10-15 \mu$ in diameter . . . . . . . . . . . . . Nais inornata

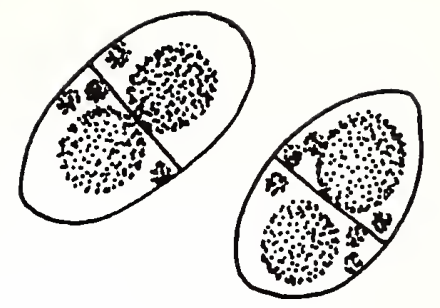

6 (2) Ascospores exclusively 2-celled

6 (2) Ascospores 2- to 4-celled ... (see also Phragmosporae) Leptosphaeria (p. 29)

7 (6) Ascospore wall verruculose Didymosphaeria (p. 23)

7 (6) Ascospore wall smooth 8

8 (7) Ascospores predominantly larger than $33 \mu$

8 (7) Ascospores usually smaller than $33 \mu$ .10

9 (8) Ascospore cells unequal in size and shape; lower half cylindrical; upper half pointed . . . . . $\ldots \ldots \ldots \ldots \ldots$. . . . . . . . . . . . . . . . . . . . . . . . . . . 23)

9 (8) Ascospore cells equal in size and shape, straight or slightly curved Leptosphaeria (p. 29)

10 (8) Ascospore 2-celled, usually unequal in size, occasionally biturbinate Microthelia linderi

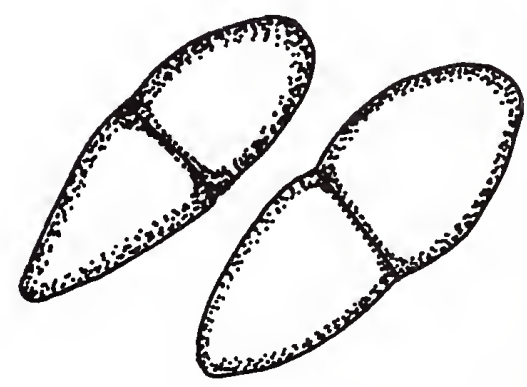

10 (8) Ascospore more than 2-celled, equal in size Leptosphaeria (p. 29) 
11 (1) Ascospores surrounded by a thin or thick gelatinous sheath but without protruding appendages of any kind

11 (1) Ascospores may lack a gelatinous sheath but possessing apical and/or equatorial appendages . . . . . . 13

12 (11) Ascospores to $15 \mu$ long, pigmented, surrounded by a thin gelatinous sheath Massariella maritima

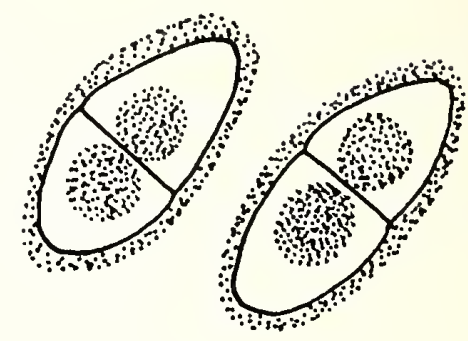

12 (11) Ascospores to $35 \mu$ long, hyaline, surrounded by an undulant, gelatinous sheath ..... Didymosamarospora euryhalina

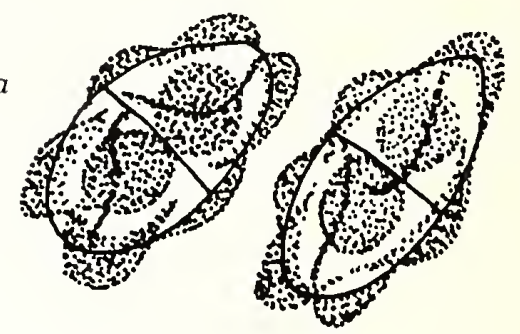

13 (11) Ascospores provided with appendages or processes in both apical and equatorial positions $\ldots \ldots 23$

13 (1I) Ascospores provided with appendages or processes at either one or both apices but without such structures around the equator or midseptum $\ldots \ldots \ldots \ldots \ldots$

14 (13) Spore appendages usually at one end only 18

14 (13) Spore appendages always occurring at both ends 15

15 (14) Spores with a single appendage at each end

15. (14) Spores with 2-7 appendages at each end 16 
17 (16) Appendages usually 3 at each end (sometimes 4-7), terminal or subterminal, stiff, thin, tapering, sometimes curved, to $40 \mu$ long . . . . . . . . . . . . . Corollospora (p. 22)

17 (16) Appendages 4-6 at each end, bulbous at base, radiating, attenuate, semirigid, mostly to $30 \mu$ long . . . . . . . . . . . . . . . . . . . Halosphaeria (p. 23)

18 (14) Appendages radiating, stiff or bristlelike ....... $\ldots \ldots \ldots \ldots$ Keissleriella blepharospora

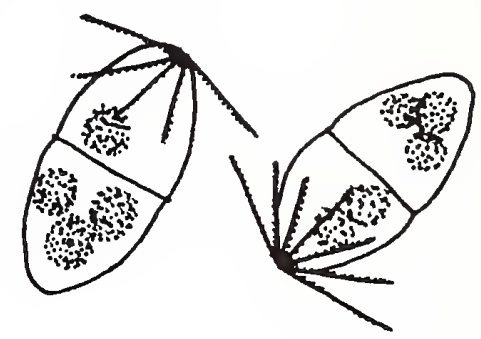

19 (18) Spores cylindrical, to $70 \mu$ long Halosphaeria (p. 23)

19 (18) Spores elipsoidal, thick-walled, to $35 \mu$ long . . (see also Phragmosporae) . . . . Lentescospora submarina

(15) Ascospores with a short, gelatinous appendage at each end (see also Phragmosporae) Lentescospora submarina

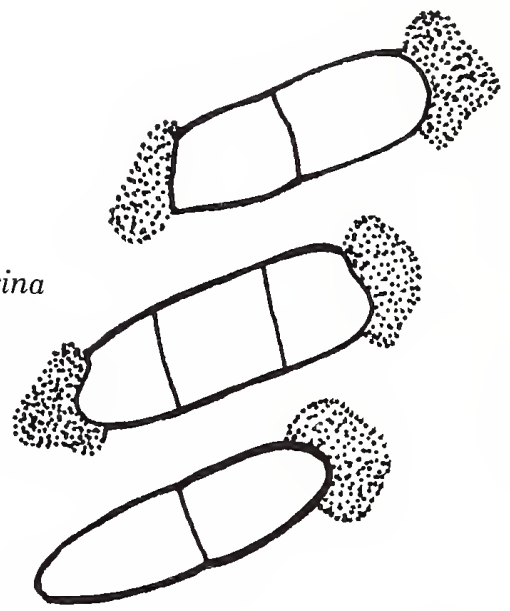

20 (15) Ascospore appendages variously shaped 
22 (21) Ascospores ellipsoidal, never elongate, under $30 \mu$ in length: with a caplike or globose, thick, polymorphic appendage at each end; ascocarp stromatic ..... Phycomelaina laminariae

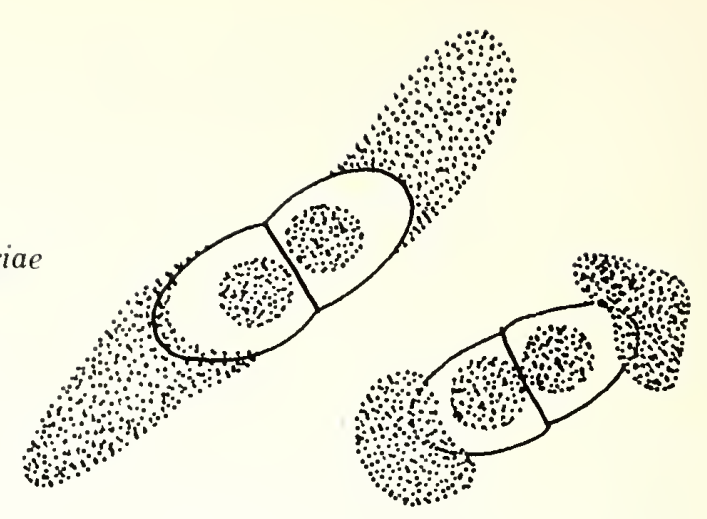

22 (21) Ascospores ellipsoidal to elongate, to $70 \mu$ in length; with a subspherical, tapering or blunt, straight or curved appendage at each end; ascocarp nonstromatic . . . . . . . Halosphaeria (p. 23)

23 (13) Equatorial appendages setae or flagellalike, arising peritrichously . . . . . . . . . Corollospora (p. 22)

23 (13) Equatorial appendages not flagellalike, not arising peritrichously . . . . . . . . . . . . . 24

24 (23) Equatorial and apical appendages provided with a small involuted cap or tip .

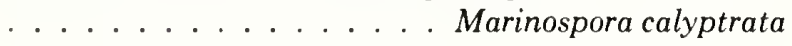
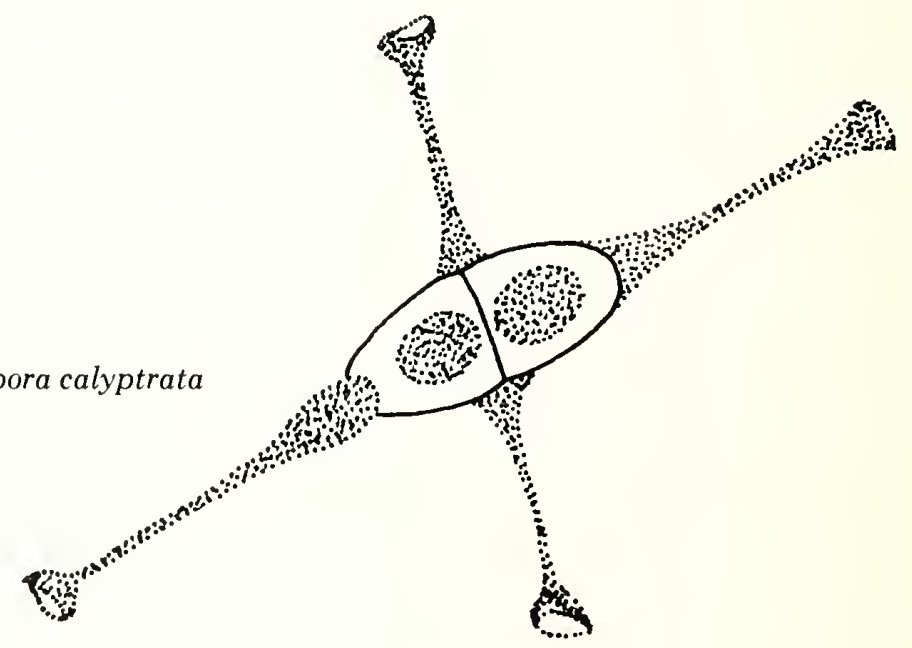

Equatorial and apical appendages not provided with small involuted caps or tips

25 (24) Ascospores totally surrounded by a gelatinous sheath; apical appendages broad, cylindrical or hollow . . . . . . . . . . . . . . . . . . Ceriosporopsis (p. 21)

25 (24) Ascospores not surrounded by a gelatinous sheath; apical appendages thin, tapering, atten-

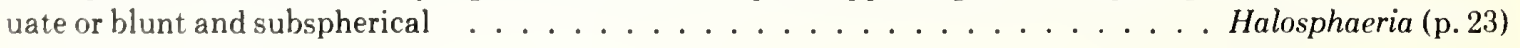




\section{Key to Species of Ceriosporopsis}

1 Ascospores provided with both a tapering, gelatinous appendage at each end, and a thick, collarlike or several wedge-shaped processes around the septum . . . . . . . C. tubulifera

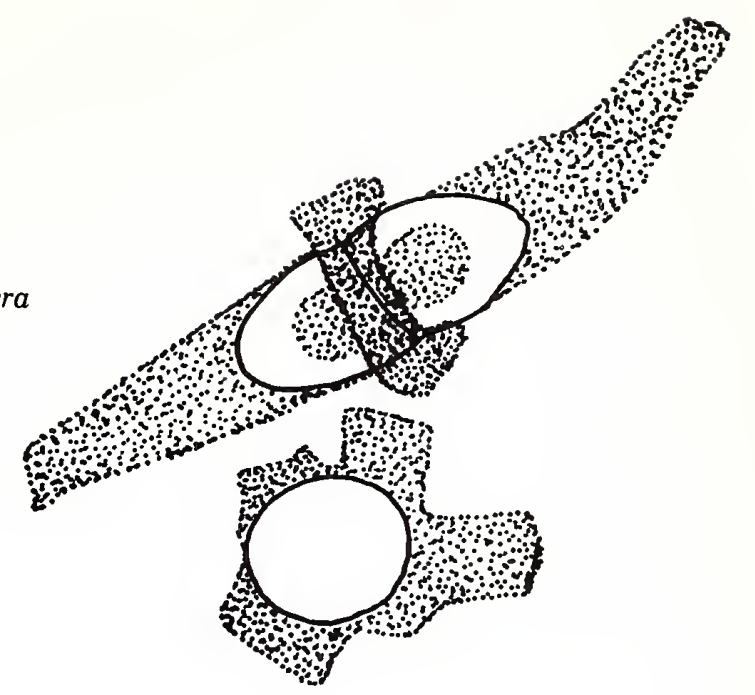

Ascospores provided with only a tapering, gelatinous appendage at each end $\ldots \ldots \ldots \ldots$

2 (1) Appendages broadly filiform, tapering, to $8 \mu$ thick at base ................ halima

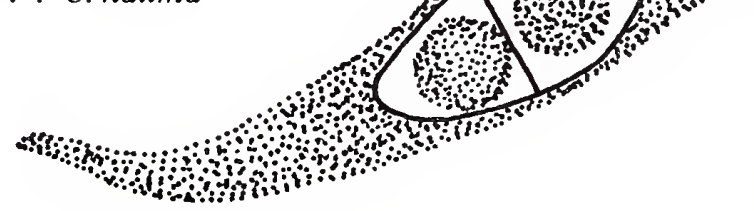

2 (1) Appendages thin, filiform, tapering, deliquescent, to $45 \mu$ long . . . . . . . C. cambrensis

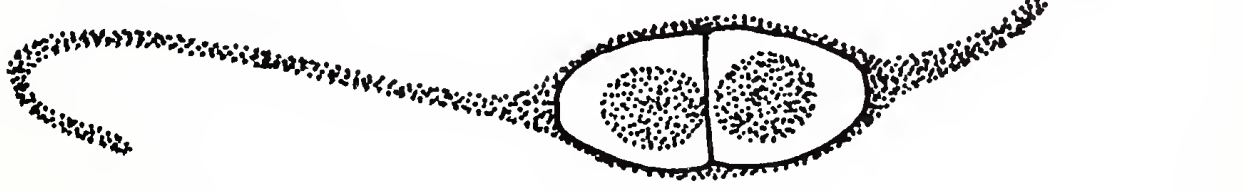


2 (1) Spores with 3 (sometimes more) terminal or subterminal appendages at each end . . . . C. trifurcata

2 (1) Spores with one slender appendage at each end and several hairlike ones equatorially

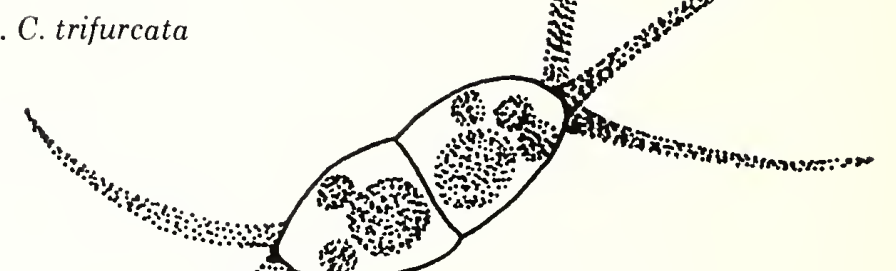

3 (1) Apical appendages single, cylindrical, hornlike, thick; equatorial ones hairlike

. C. maritima
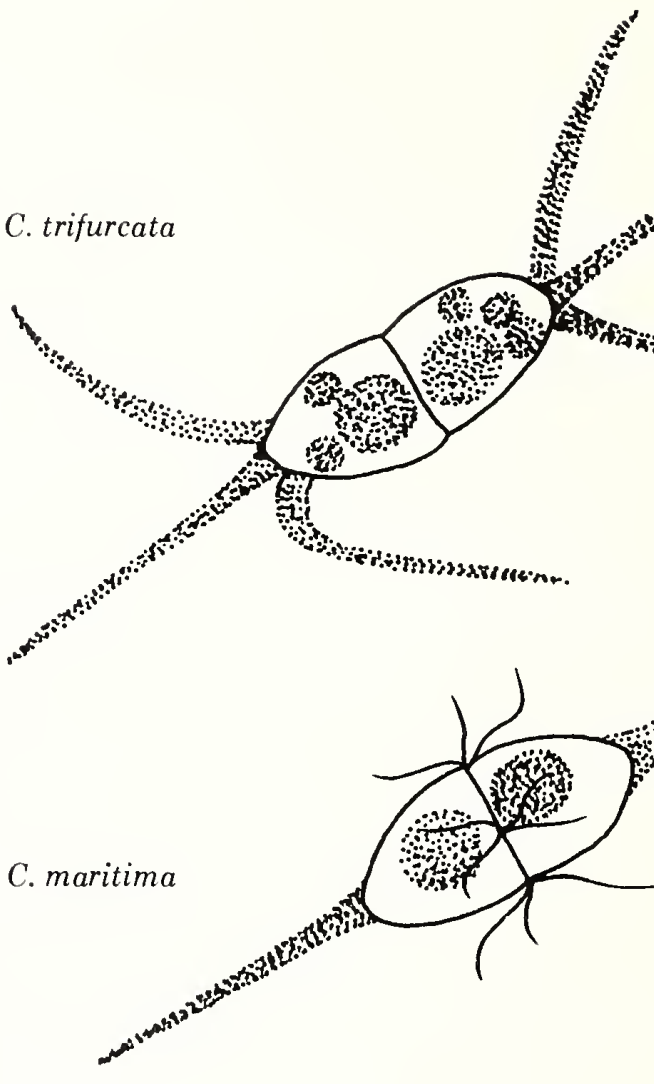


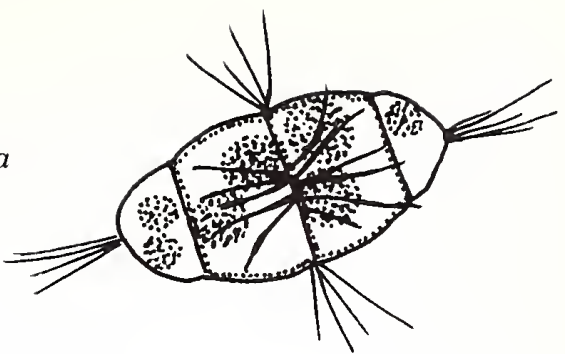

4 (3) Spores predominantly 6-celled

C. comata

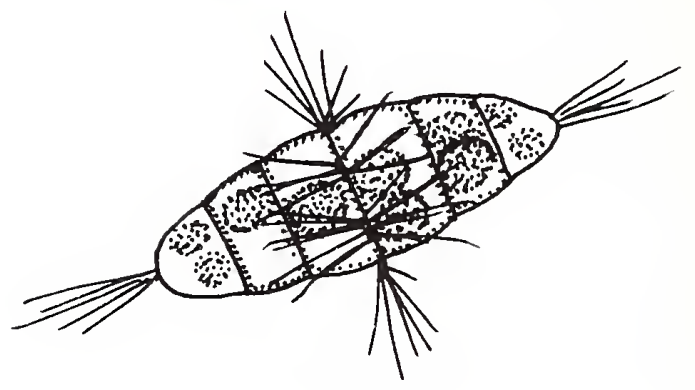

Key to Species of Didymosphaeria
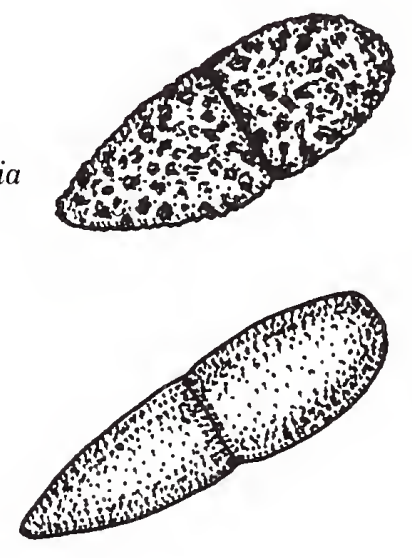

Key to Species of Halosphaeria 
2 (1) Apical appendages short, caplike or cup-shaped; equatorial ones 3 or 4 in number, crescent-shaped, and more or less

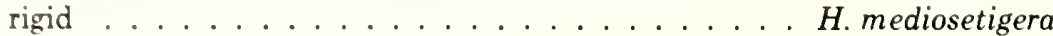

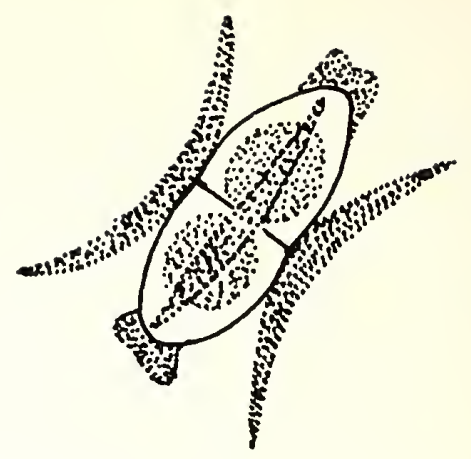

2 (1) Apical appendages long, narrow, flexible; equatorial ones similar, or a collarlike annulus . . . . . . 3

3 (2) Equatorial appendages 3 or 4, narrow and flexible H. appendiculata

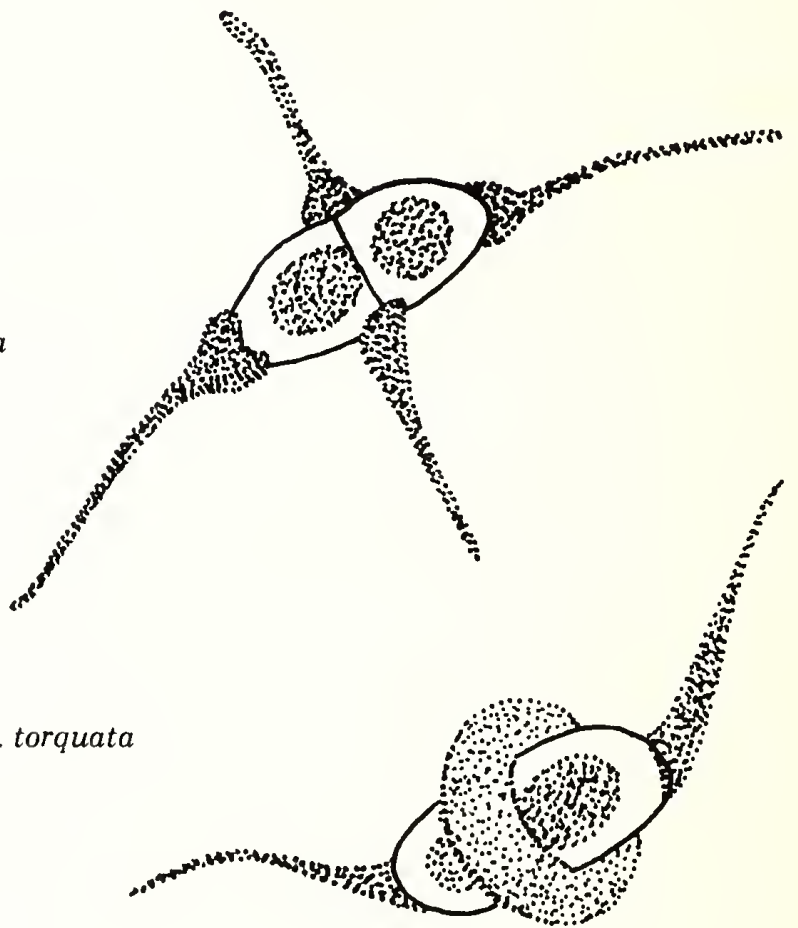

3 (2) Equatorial appendage a collarlike annulus .... H. torquata

4 (1) Ascospores with a single appendage at one or both apices; these caplike or subspherical, terminal or subterminal, blunt, tapering or scooplike 5

4 (1) Ascospores with two to several appendages at each apex; these fingerlike, stellate, mustacheshaped, hooked, or pleomorphic 
5 (4) Appendage short, subspherical, usually only at one end; spores to

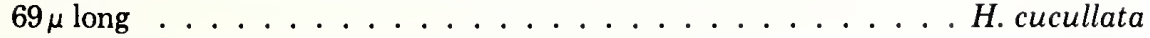

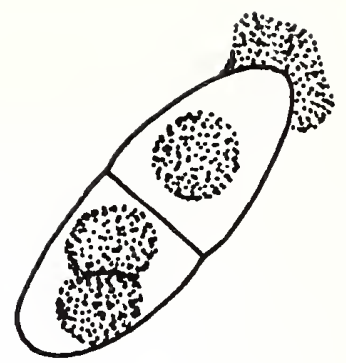

5 (4) Appendages blunt, attenuate, hooked or tapering; spores to $35 \mu$ long $\ldots \ldots \ldots$

6 (5) Appendages blunt, scooplike, occasionally subspherical, to $10 \mu$ wide .......................... trullifera

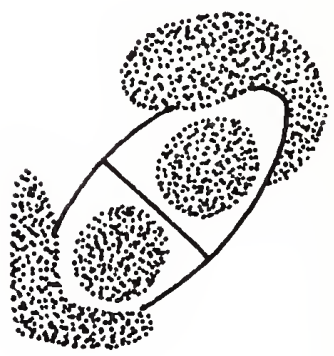

6 (5) Appendages terminal or subterminal, hooked, curved or straight, may be subspherical at first, then becoming

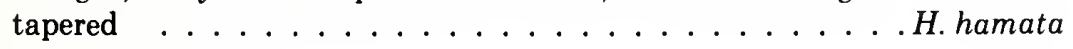

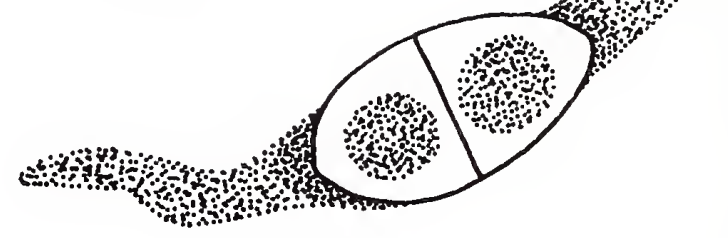

7 (4) Ascospores rhomboidal or diamond-shaped; thick-walled . . . H. pilleata

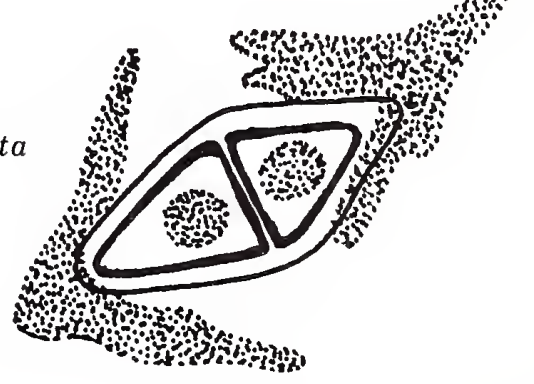

7 (4) Ascospores more or less ellipsoidal; not thick-walled 
9 (G) Appendages rigid, acuminate, directed parallel or at right angles to each other ............... quadricornuta

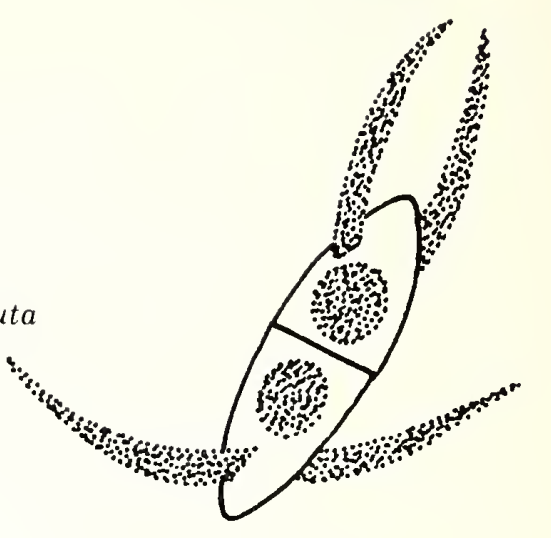

9 (8) Appendages gelatinous, stout or tapered, mustache-shaped . H. maritima

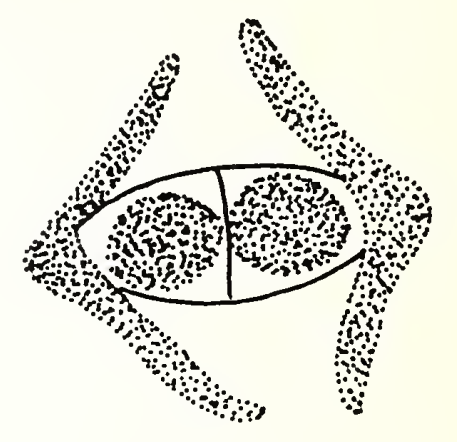

10 (8) Spores provided with 3-5 terminal or subterminal, straight or curved, tapering, bulbous appendages to $20 \mu$ long; these being individually attached ............... salina

10) (8) Spores provided with 4-6 terminal, attenuate, tapering, semirigid, radiating appendages to $35 \mu$ long; these forming a common palmlike base at the spore apices H. quadriremis

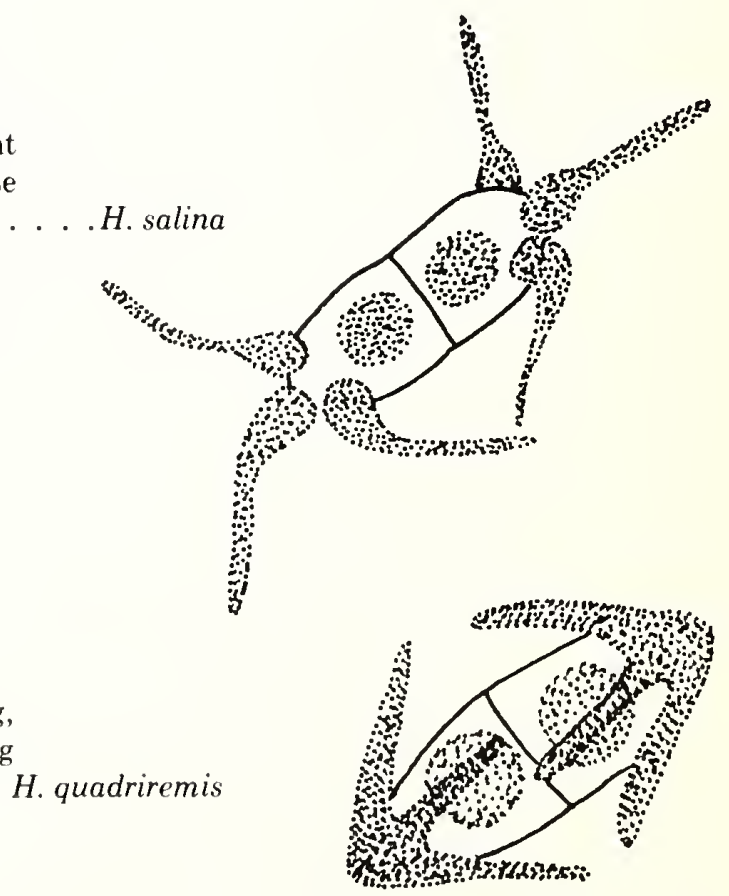


Ascospores without appendages; with or without a gelatinous sheath $\ldots \ldots \ldots$

2 (1) Ascospores provided with apical or equatorial appendages, but not both . . . . . . . . . . 3

2 (1) Ascospores provided with apical as well as equatorial appendages . . . . . . . . . Corollospora (p. 22)

3 (2) Appendages positioned around the equatorial septum ......

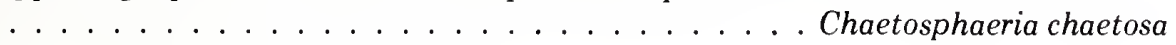

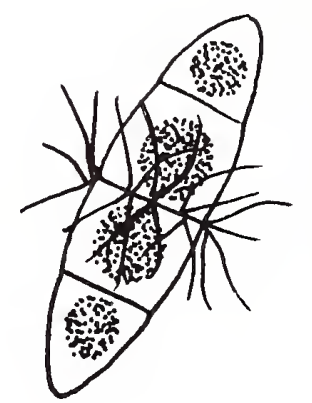

3 (2) Appendages positioned at one or both spore apices . . . . . . . . . . . . . . . . . 4

4 (3) Ascospores provided with 3 or 4 slender, radiating appendages at one end .............. Torpedospora radiata

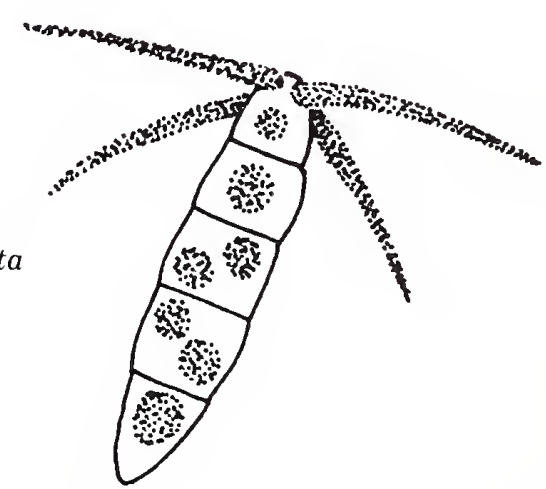

4 (3) Ascospores provided with a single appendage at one or both apices 
5 (4) Appendages short, blunt, at one or both ends ... (see also Didymosporae) . . . . . . . . Lentescospora submarina

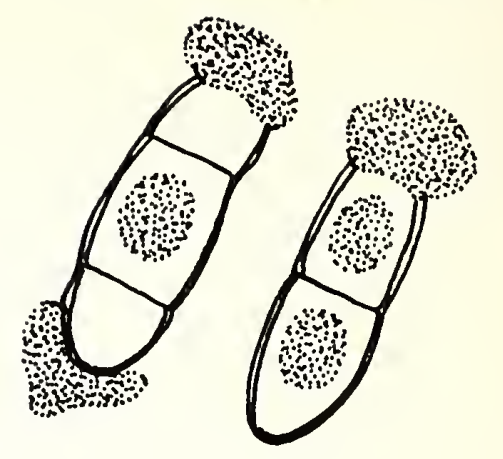

6 (1) Spores 2-to 4-celled

6 (1) Spores 4- to 8-celled

7 (6) Ascospores provided with an amorphous, gelatinous sheath generally surrounding the midportion of, and usually as thick as, the

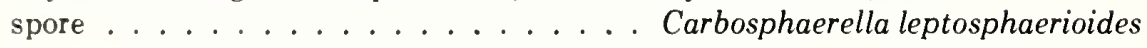

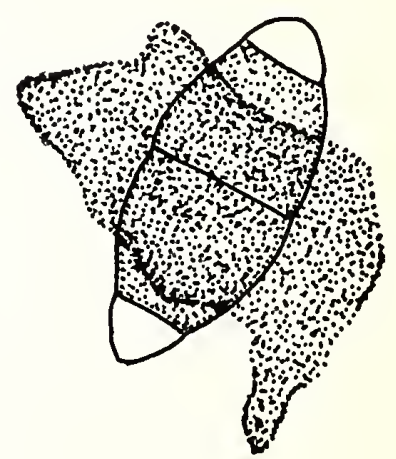

7 (6) Ascospores either without a sheath, or if one is present, not amorphous, but thin and surround-

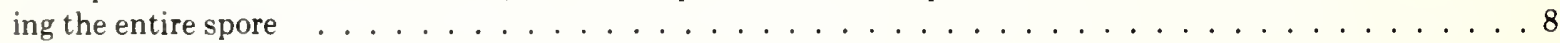

8 (7) All cells hyaline and more or less equal in size

Sphaerulina (p. 31)

8 (7) All or some cells yellow to yellow-brown, or brown to dark brown; if all hyaline, penultimate cell largest

Leptosphaeria (p. 29)

y (5) Ascospores hyaline, end cells attenuate and curved

Sphaerulina (p. 31)

9 (6) Ascospores hyaline or yellow-brown, end cells not attenuate and curved

Leptosphaeria (p. 29) 


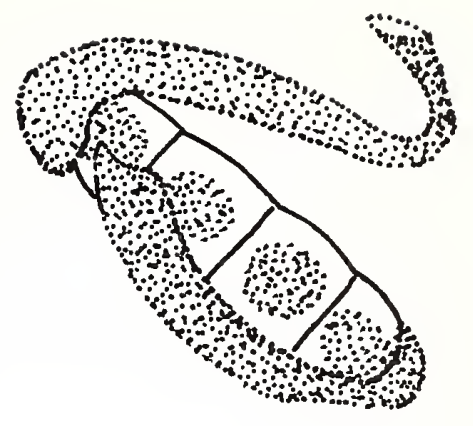

H. viscidula

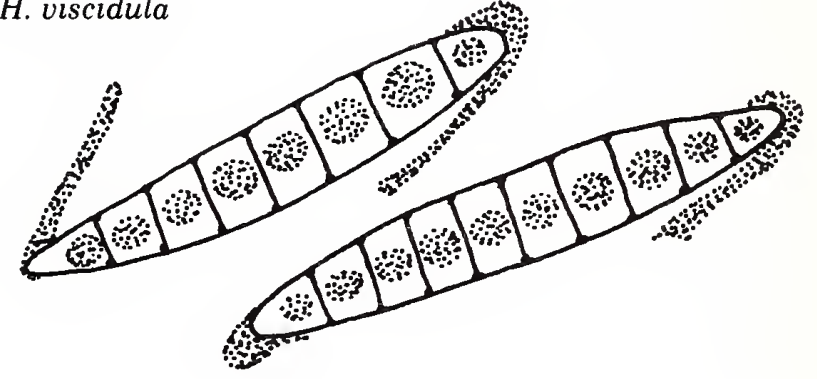

Key to Species of Leptosphaeria

Ascospores 2- to 4-celled

2 (1) Ascospores surrounded by a gelatinous sheath . . . L. halima

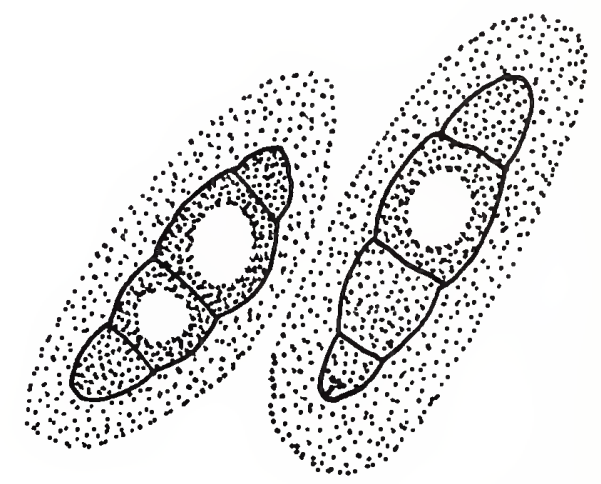

2 (1) Ascospores without a gelatinous sheath 
3 (2) Spores with hyaline end-cells and yellow-brown to brown midcells . . . . . . . . . . . . . discors
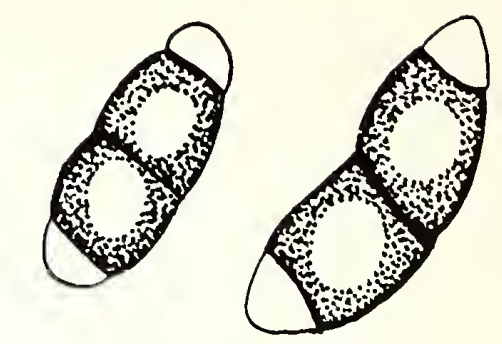

4 (3) Mature spores longer than $35 \mu \ldots \ldots$. . . . . marina

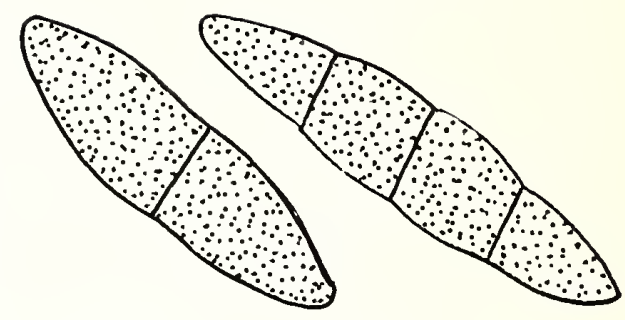

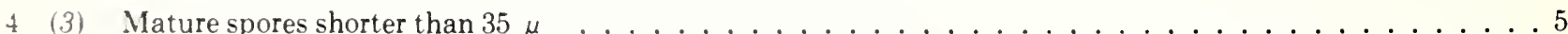

5 (4) Ascospores 2- to 4-celled, brown or dark brown ..... L. oraemaris

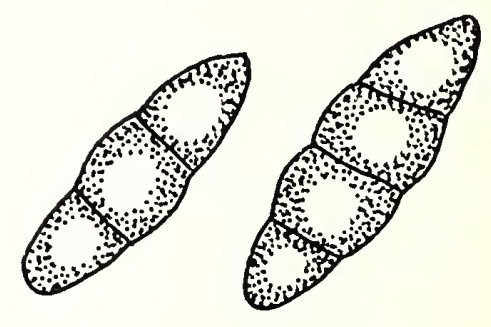

5 (4) Ascospores 4-celled, hyaline, penultimate cell usually largest

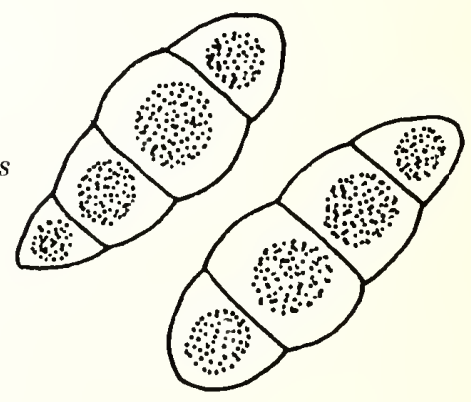


(1) Spores without a sheath ........ albopunctata

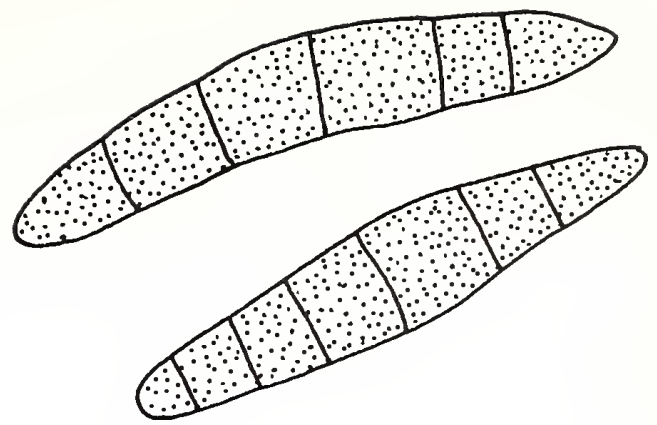

7 (6) Ascospores 4- or 5-celled, hyaline, penultimate cell usually largest; sheath thick, to $11 \mu \ldots \ldots$. . . . contecta

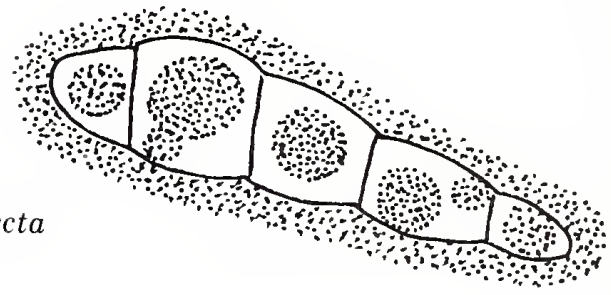

7 (6) Ascospores 4- to 6-celled, yellow to yellow-brown, midcells largest, sheath thin . . . . . . . L. maritima

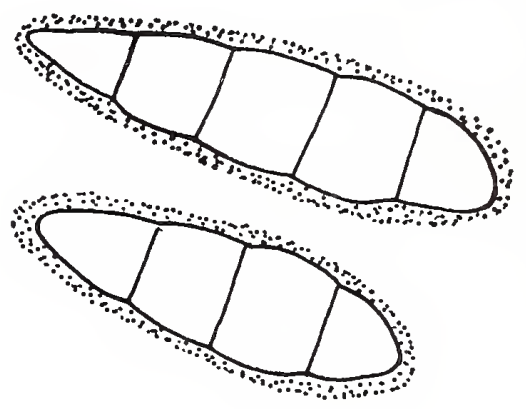

\section{Key to Species of Sphaerulina}

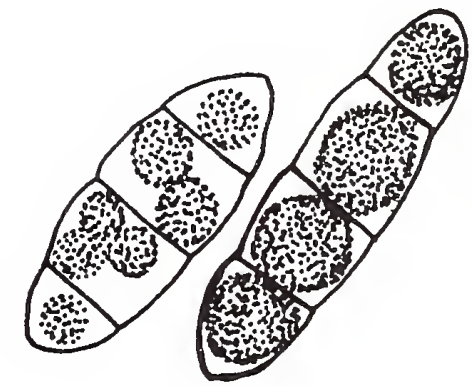

Ascospores 4- to 6-celled, to $54 \mu$ long, elongate-pyriform, one end-cell rounded, the other attenuate and curved

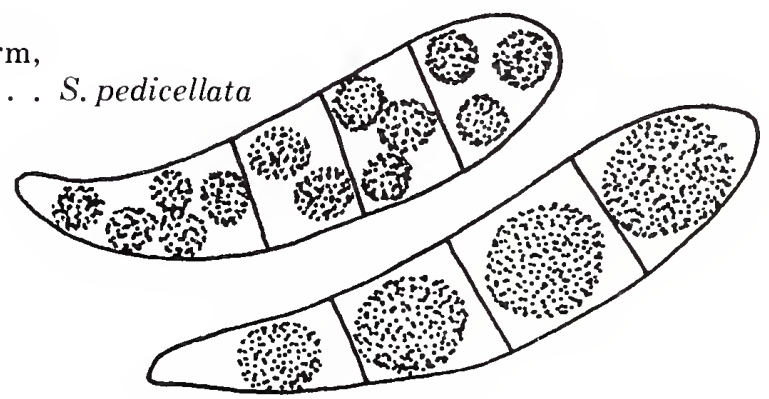




\section{KEY TO GENERA AND SPECIES OF DEUTEROMYCETES}

1 Conidia not produced; vegetative hyphae only

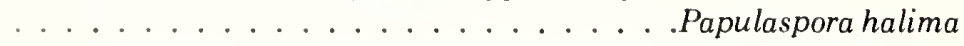

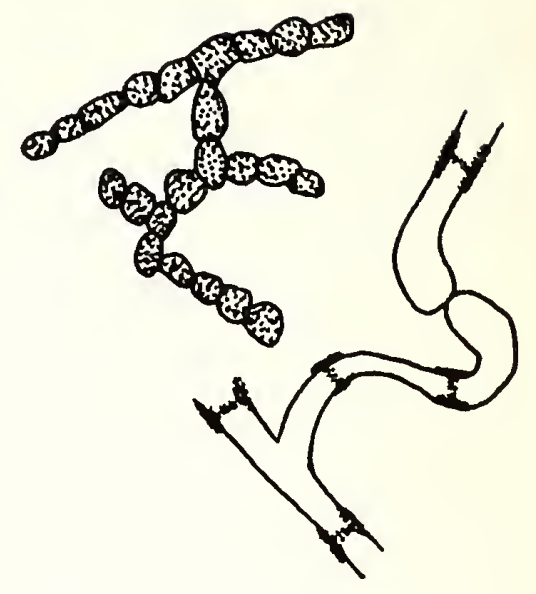

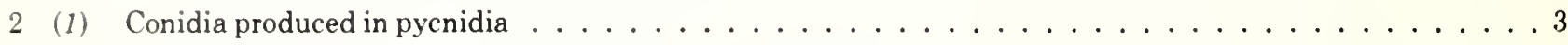

2 (1) Conidia produced directly from vegetative hyphae $\ldots \ldots \ldots \ldots \ldots$

3 (2) Conidia muriform, fuscous or yellow-brown .....

\section{Camarosporium metableticum}

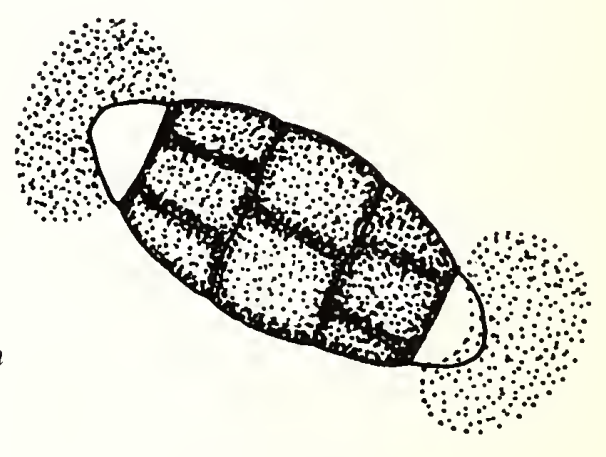

3 (2) Conidia 1- or 2-celled, hyaline to yellow-brown

4 (3) Conidia produced endogenously within bottle-shaped phialides

Phialophorophoma litoralis

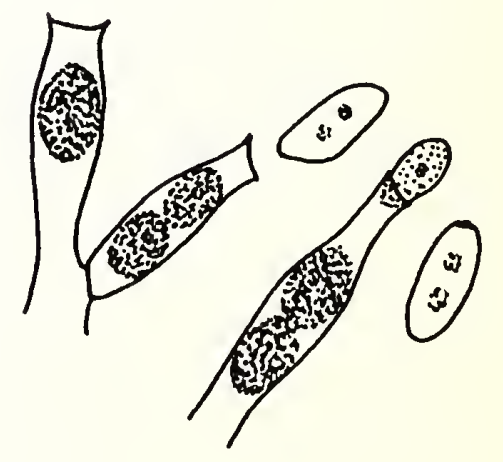


4 (3) Conidia produced exogenously on conidiophores $\ldots \ldots \ldots \ldots$

5 (4) Conidia 2 -celled, rarely 3 -celled . . . . . . . . . Diplodia oraemaris

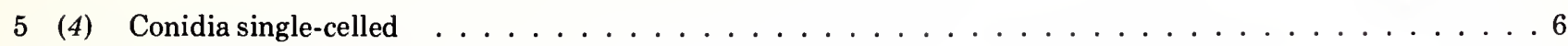

6 (5) Conidia ellipsoidal to bacilliform under $7.5 \mu \ldots \ldots$. . . . . Phoma (p. 46)

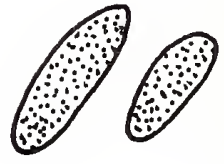

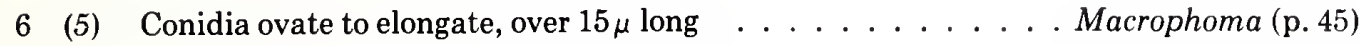

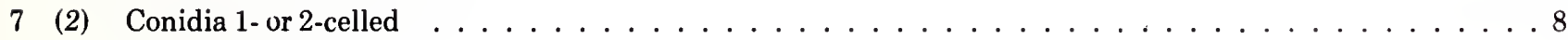

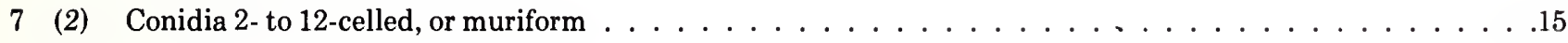

8 (7) Conidia catenulate or clustered $\ldots \ldots \ldots \ldots$

8 (7) Conidia produced individually on conidiophores or in phialides $\ldots \ldots \ldots \ldots$

9 (8) Conidia clustered on common basal cells $\ldots \ldots \ldots \ldots \ldots$

9 (8) Conidia catenulate or clustered on individual conidiophores $\ldots \ldots \ldots \ldots$ 


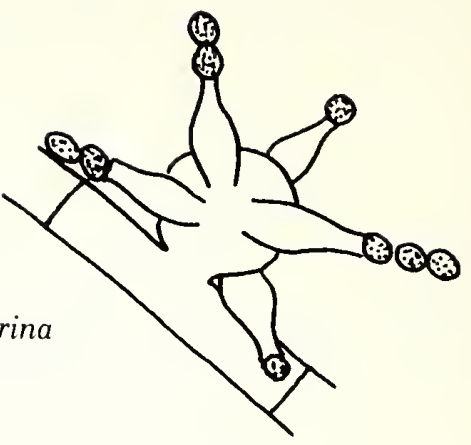

11 (10) Conidia hyaline, 2-celled, rarely single-celled, borne on peg-

like teeth of conidiophores . . . . . . . . Arthrobotrys superba

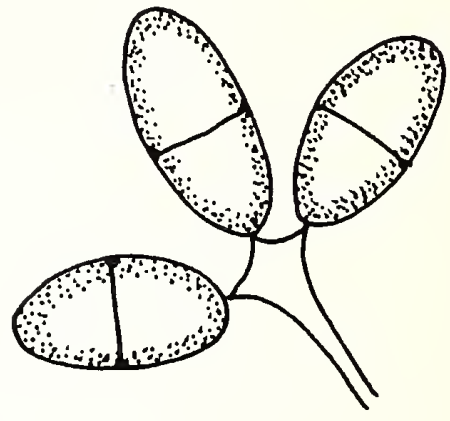

11 (10) Conidia fuscous, single-celled, rarely 2-celled, borne on basidiumlike conidiophores . . . . . . . Asteromyces cruciatus

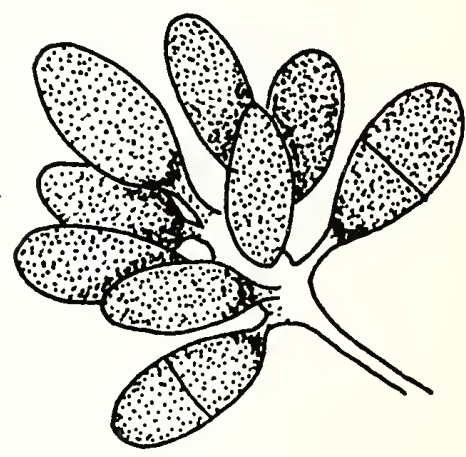

12 (9) Conidia in short chains, subglobose or ellipsoidal ...... 
13 (12) Conidial cells all uniform in diameter; conidiophores long, distinct . . . . . . . . Periconia prolifica

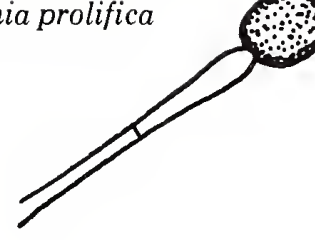

13 (12) Conidial cells increasing in diameter from base to apex; conidiophores short, indistinct ... C Cremasteria cymatilis

14 (8) Conidia staurosporous, single-celled, borne in phialides with collarlike $\operatorname{rim} \ldots \ldots$. . . . . . . . . . . . . .

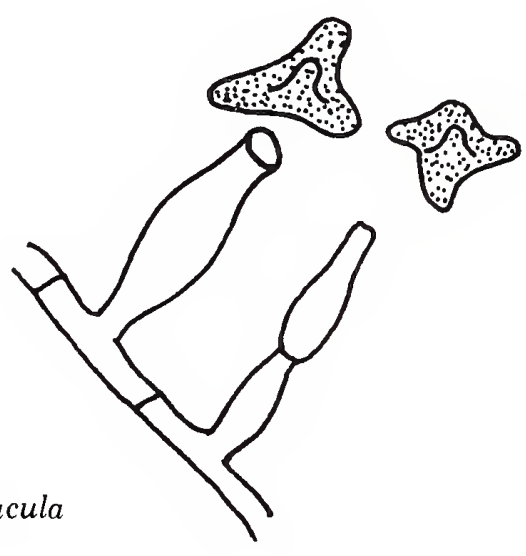

14 (18) Conidia obpyriform, 1- or 2-celled, produced on conidiophores . .

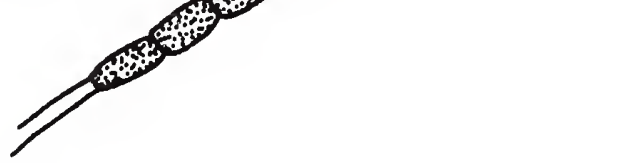

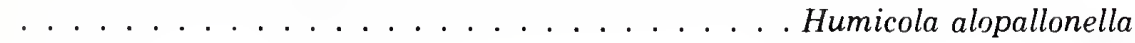

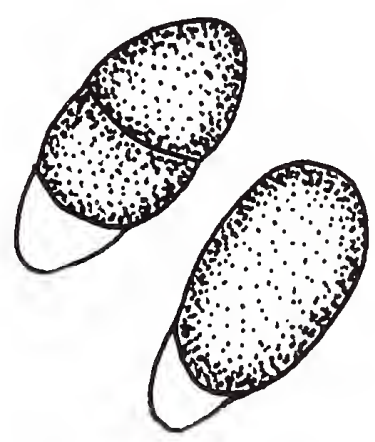


17 (16) Conidial cells hyaline throughout ....

.......... Varicosporina ramulosa
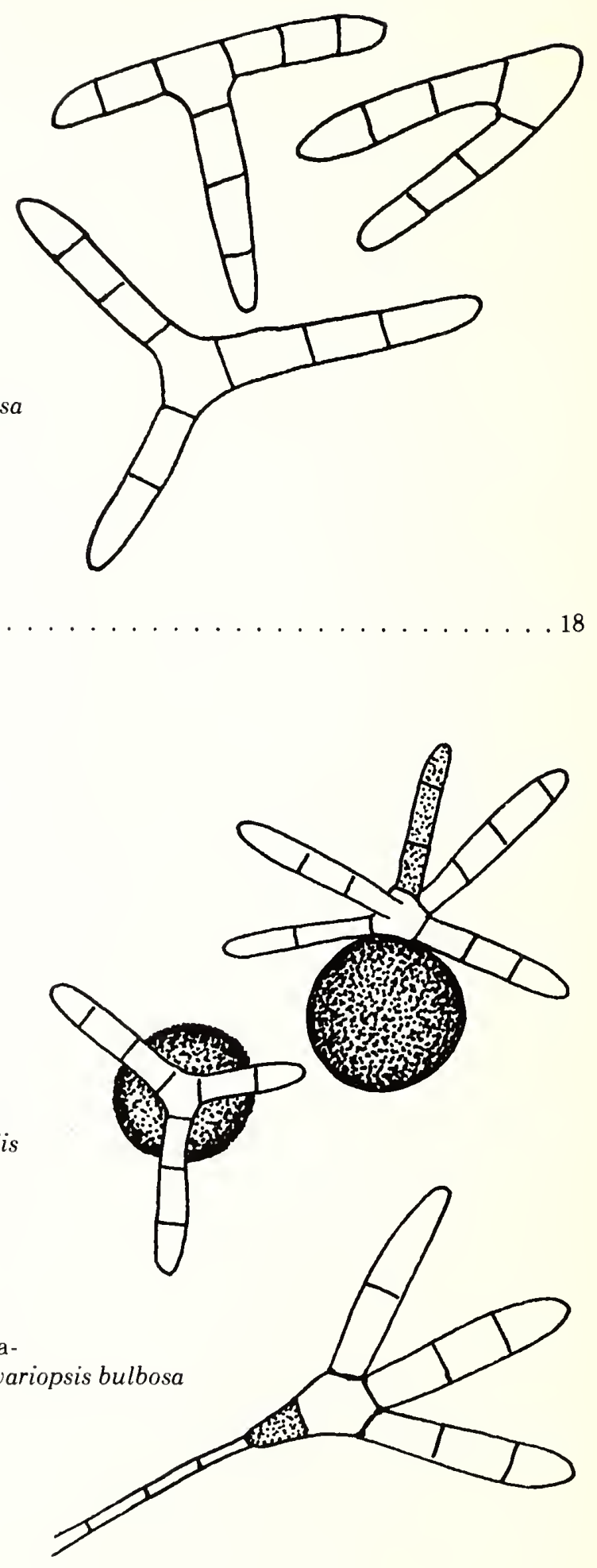

18 (17) Basal conidial cell spherical, dark brown to black, $20 \mu$ in diameter or larger

Orbimyces spectabilis

18 (17) Basal conidial cell ellipsoidal, light brown, $20 \mu$ in diameter or smaller . Clavariopsis bulbosa 
19 (16) Conidia pyriform, apical cell often attenuate, to

$80 \mu$ long . . . . . . . . Alternaria maritima

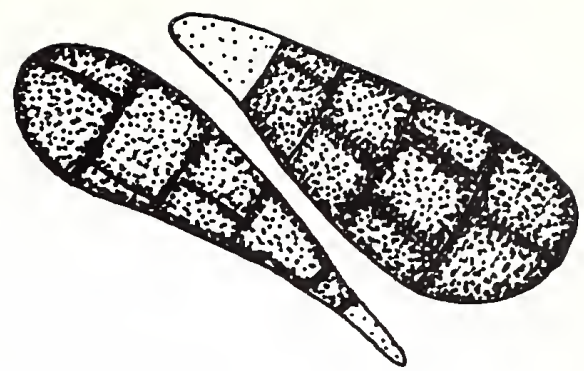

19 (16) Conidia variously shaped, apical cell not attenuate, under $50 \mu$ long . . . . . . . . . . . . . . 20

20 (19) Conidia globose to ellipsoidal, $19-32 \mu$ long; conidiophores absent or reduced to simple pedicels . . . . . . . Stemphylium maritimum
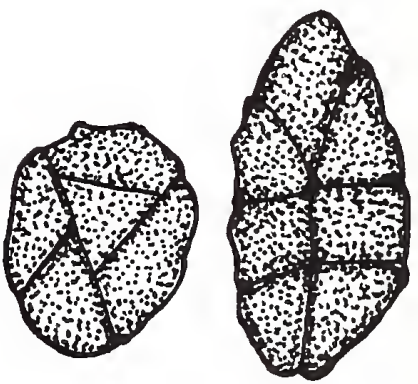

20 (19) Conidia clavate, pyriform; conidiophores distinct

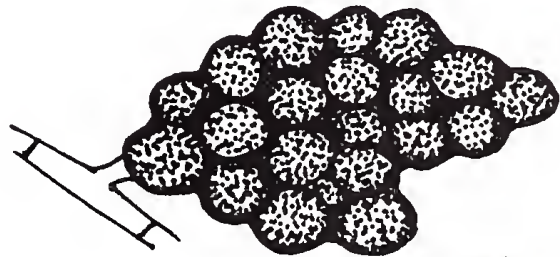

21 (20) Conidia fuscous or dark brown, cells more or less parallel arising from a single basal cell ... . . .

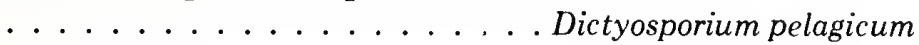

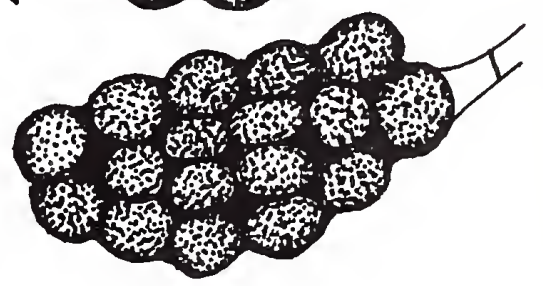

21 (20) Conidia dark brown to black, cells irregular; 1 to 3 light basal cells may occur . . . . . . . . . Monodictys pelagica

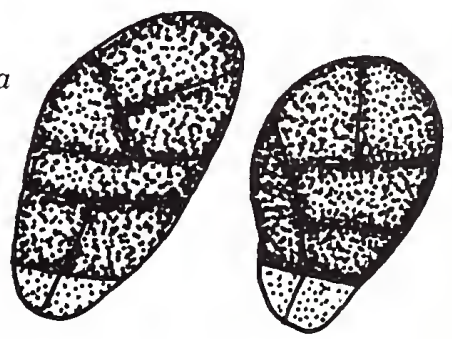


23 (22) Conidia cylindrical to ellipsoidal, straight or slightly curved, smooth or slightly echinulate: apical tip may be slightly thickened . . . . . . . . . . . . . Dendryphiella (p. 38)

23 (22) Conidia clavate, curved or straight; cells increasing in size from base to apex

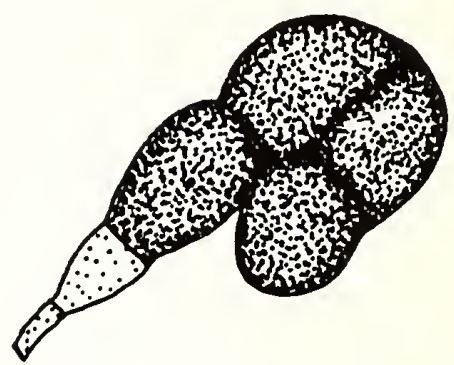

24 (23) Conidia 3- to 9-celled, curved

24 (23) Conidia 3-to 6-celled, straight ....

Trichocladium achrasporum
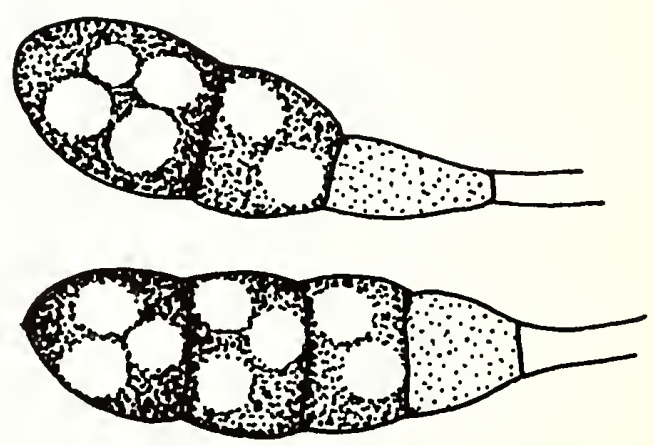

Key to Species of Dendryphiella 


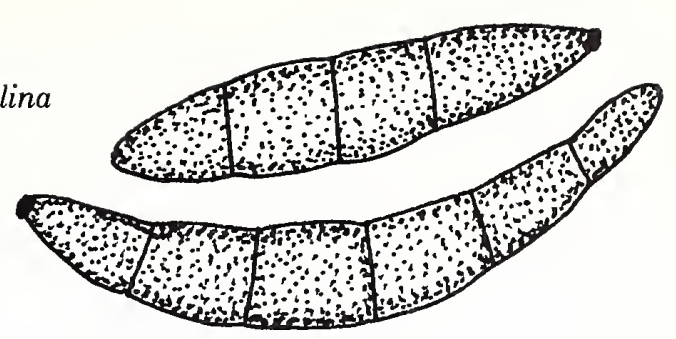

Key to Species of Zalerion

1 Conidial filament forming a more or less perfect 1 - to 3-coiled spiral ............... maritimum

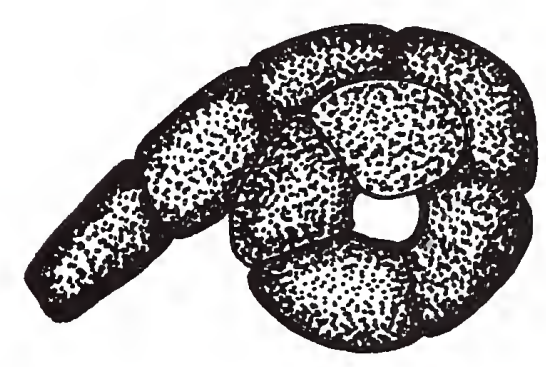

Conidial filament forming a variable, irregular spiral in 3 planes . . . . . . . . . . . Z. varium

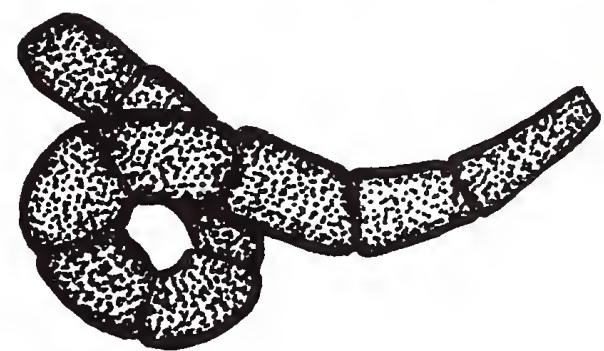

\section{ANNOTATED LIST OF SPECIES}

The following list of descriptions is arranged alphabetically. The name of each species is followed by the authority and the journal in which the original description or current valid name of the organism was first published. Lists of synonyms have been restricted to those which have come into existence since 1970 . For a recent, thorough treatment of the systematics and taxonomic positions of higher marine fungi see Kohlmeyer (1972) and Hughes (1975).

\section{Phylum EUMYCOPHYTA}

\section{Class ASCOMYCETES}

Amylocarpus encephaloides Currey

Proc. R. Soc. Lond. 9:119. 1857-1859.

Ascospores hyaline, globose to subglobose, single-celled, guttulate, 8-16 $\mu$ in diameter, with 10-15 rigid, awl- shaped appendages arising from various positions along the wall, $5-10 \mu$ long.

Ascocarp a cleistothecium 160-500 $\times 200-670 \mu$.

In driftwood and other cellulosic material.

Carbosphaerella leptosphaerioides Schmidt

Nat. Nat. Mecklenburg 7:9-10. 1969.

Ascospores 4-celled, 25-40 $\times 16-20 \mu$, broadly ellipsoidal; the two central cells large, dark brown; apical cells small, hyaline; constricted at septa; provided with a gelatinous, hyaline amorphous sheath.

In driftwood and other cellulosic material.

\section{Ceriosporopsis cambrensis Wilson}

Trans. Br. Mycol. Soc. 37:276. 1954.

Ascospores hyaline, ellipsoidal to subcylindrical, ends obtuse, 2-celled, one large guttule per cell, may or may not be constricted at the septum, $22-33 \times 5-14.5 \mu$; provided at each end with a single, filiform, deliques- 
cent appendage to $45 \mu$ in length; wholly or partially surrounded by a gelatinous sheath.

In driftwood, reeds, and other cellulosic material.

\section{Ceriosporopsis halima Linder}

Farlowia 1:409. 1944.

Ascospores hyaline, ellipsoidal, oblong-ellipsoidal or fusiform, 2-celled, 1-2 guttules per cell, may be constructed at septum, $17-40 \times 6-14 \mu$; provided at each end with a single, broadly filiform, tapering appendage $5-8 \mu$ : in diameter, wholly or partially surrounded by a gelatinous sheath.

In driftwood, reeds, and other cellulosic material.

Ceriosporopsis tubulifera (Kohlm.) Kirk in Kohlm.

Can. J. Bot. 50:1953. 1972.

Syn. Halosphaeria tubulifera Kohlm.

Nova Hedwigia 2:312. 1960.

Ascospores hyaline, ellipsoidal, 2-celled, slightly constricted at septum, 1 or 2 guttules per cell, 14.5$23 \times 8.5-11 \mu$; provided at each end with a broad. flared, tapering, tubular appendage, 9-15 $\times 5-8.5 \mu$ long, in addition, with a 4.5-8.5 $\mu$ thick equatorial collar which eventually splits into several wedgeshaped fragments.

In driftwood, reeds, and other cellulosic material.

Chaetosphaeria chaetosa Kohlm.

Nova Hedwigia 6:307-308. 1963.

Ascospores hyaline, fusiform, or elongate to ellipsoidal, 4-celled, each cell guttulate, constricted at septa, 25.5$36.5 \times 7.5-11.5 \mu$; provided around the midseptum with numerous, stiff setae, $6-7.5 \mu$ long.

Ascus provided with a disc-shaped, perforated apparatus.

In driftwood and other cellulosic material.

Corollospora comata (Kohlm.) Kohlm.

Ber. Dtsch. Bot. Ges. 75:126. 1962.

Ascospores predominately 6-celled, fuscous to gray around midseptum, end cells hyaline, fusoid, multiguttulate, constricted at septa, $31-54 \times 12-17 \mu$; provided with a tuft of up to 15 hairs at each end and additionally with hairlike tufts at the midseptum; apical hairs to $15 \mu$

long, equatorial ones to $20 \mu$ long.

In driftwood and other cellulosic material.

Corollospora cristata (Kohlm.) Kohlm.

Ber. Dtsch. Bot. Ges. 75:126. 1962.

Ascospores predominately 4-celled, ellipsoidal, fuscous to gray around midseptum, end cells hyaline, multiguttulate, constricted at septa, 24-41 $\times 8.5-16.5 \mu$; provided with a tuft of hairs at each end and additionally with hairlike tufts at the midseptum; apical hairs to $8 \mu$ long, equatorial ones to $9 \mu$ long.

In driftwood and other cellulosic material.

Corollospora lacera (Linder) Kohlm.

Ber. Dtsch. Bot. Ges. 75:126. 1962.

Ascospores 4- to 6-celled (predominately 5-celled) fusoid or oblong-ellipsoidal, fuscous to brownish around midseptum, end cells hyaline, constricted at septa, 1 large guttule per cell, $39-63 \times 10-15 \mu$; provided at each end with a slender, subcylindrical, slightly curved appendage, approximately hornlike in general shape, to $20 \mathrm{u}$ long; in addition, the midseptum is provided with several flexible setae arising peritrichously.

In driftwood, reeds, calcareous substrates associated with sandy beaches. Rare.

\section{Corollospora maritima Werdermann}

Notizbl. Bot. Gart. Mus. Berlin-Dahlem 8:248. 1922.

Ascospores 2-celled, hyaline to pale yellow around septum, fusoid to ellipsoidal, 1 or 2 guttules per cell, conspicously constricted at septum, $20-53 \times 6.5-14 \mu$; each end provided with a slender, tapering, rigid or semirigid appendage to $20 \mu$ long; in addition, the septum is provided with several flexible setae arising peritrichously.

In driftwood, cellulosic materials, and calcareous fragments.

Corollospora trufurcata (Höhnk) Kohlm.

Ber. Dtsch. Bot. Ges. 75:126. 1962.

Ascospores 2-celled, 26-38.5 $\times$ 9-16.5 $\mu$, hyaline, fusoid to ellipsoidal, constricted at septum, 1-4 guttules in each cell; provided at each end with 3 (sometimes 4-7) terminal or subterminal, tapering, curved, deciduous appendages to $39 \mu$ long.

In driftwood, cellulosic materials, and calcareous fragments.

Didymella fucicola (Suth.) Kohlm.

Phytopathol. Z. 63:342. 1968.

Ascospores 2-celled, 16-23 $\times 6-8 \mu$, hyaline, ovoid to ellipsoidal, constricted at septum, one cell slightly larger than the other.

Ascocarp a pseudothecium; asci bitunicate, 55-115 $\times$ 10-15 $\mu$.

Reported only in Fucus.

\section{Didymosamarospora euryhalina Johnson \& Gold}

J. Elisha Mitchell Sci. Soc. 73:104. 1957.

Ascospores 2-celled, 25-34 $\times 12-17 \mu$, hyaline, broadly ovoid or broadly fusoid, ends rounded or slightly tapered, 1 guttule per cell, may be slightly constricted at septum, surrounded by a gelatinous, undulant sheath.

In Juncus and other culms.

Didymosphaeria danica (Berlese) Wilson \& Knoyle

Trans. Br. Mycol. Soc. 44:57. 1961.

Ascospores 2-celled, $33-44 \times 5-8 \mu$, hyaline to slightly yellow, broadly ellipsoidal or fusiform-ellipsoidal, lower half of spore shorter and cylindrical, the upper half slightly larger and pointed.

Ascocarp a pseudothecium; asci bitun i cate, $83-94 \times 12$ $14 \mu$.

Reported only in Chondrus. 
Didymosphaeria enalia Kohlm.

Ber. Dtsch. Bot. Ges. 79:28. 1966.

Ascospores 2-celled, 15.5-23 $\times 6.5-11 \mu$, dark brown, ellipsoidal to broadly ellipsoidal, constricted at septum, verruculose.

Ascocarp a pseudothecium; asci bitunicate 117-135 $\times$ 12.5-15.5 $\mu$.

In driftwood. Uncommon in colder waters.

\section{Haligena elaterophora Kohlm.}

Nova Hedwigia 3:87-88. 1961.

Ascospores 4- or 5-celled, ellipsoidal to oblong, 24-54.5 $\times 10-19.5 \mu$, hyaline, ends rounded; provided at each end with a single, long, curved, grooved, terminally inflated appendage.

In wood and other cellulosic material.

\section{Haligena viscidula J. \& E. Kohlm.}

Nova Hedwigia 9:92. 1965.

Ascospores 6- to 12-celled, 37.5-89 $\times$ 4-6.5 $\mu$, hyaline, fusiform to fusiform-cylindrical, each cell with a single guttule, may be slightly constricted at septa; provided at each end with a short, caplike or threadlike appendage 6-10 $\mu$ long.

In driftwood and other cellulosic material.

Haloguignardia oceanica (Ferd. \& Winge) Kohlm.

Mar. Bio. 8:344. 1971.

Syn. Phyllachorella oceanica Ferd. \& Winge

Mycologia 12:102-103. 1920.

Ascospores single-celled, 20-31.5 $\times 9-14 \mu$, hyaline, ellipsoidal to fusiform, ends rounded; provided at each end with a small, gelatinous, deciduous appendage.

Ascocarp a stromatic structure with unitunicate asci.

In Sargassum.

\section{Haloguignardia tumefaciens (Cribb \& Herbert) Cribb \& Cribb}

Pap. Univ. Queensland Dep. Bot. 3:98. 1956.

Ascospores single-celled, $30-59 \times 10-21.5 \mu$, hyaline, broadly ellipsoidal or fusiform-ellipsoidal, ends tapered, may be densely granular around the equator; provided at each end with an acute, nipplelike appendage surrounding the peglike apical tip of the spore.

In Sargassum.

\section{Halonectria milfordensis Jones}

Trans. Br. Mycol. Soc. 48:287. 1965.

Ascospores single-celled, 16.5-29 $\times 2-3.5 \mu$, hyaline, fusiform to fusiform-cylindrical, straight or curved, equatorial area of spore sometimes broader than ends; multiguttulate.

In driftwood and other cellulosic material. Rare.

\section{Halosphaeria appendiculata Linder}

Farlowia 1:412. 1944.

Ascospores 2-celled, 16-30 $\times 6-14 \mu$, hyaline, ellipsoidal to ellipsoidal-cylindrical, each cell with one or more guttules, constricted at septum; provided at each end with a single, narrow, flexible, gelatinous, deliquescing appendage, and 3 or 4 similar ones equatorially, to $18 \mu$ in length.

In reeds, driftwood, and other cellulosic material.

Halosphaeria cucullata (Kohlm.) Kohlm.

Can. J. Bot. 50:1956. 1972.

Syn. Remispora cucullata Kohlm.

Mycologia 56:770. 1964.

Ascospores 2-celled, 21-69 ×6-12 $\mu$, hyaline, ellipsoidal or cylindrical, one to several guttules per cell, may be slightly constricted at septum; provided with a gelatinous, caplike or subspherical, deciduous appendage $5-10 \mu$ in diameter at one end of the spore.

In driftwood.

Halosphaeria hamata (Höhnk) Kohlm.

Can. J. Bot. 50:1956. 1972.

Syn. Remispora hamata (Höhnk) Kohlm.

Ber. Dtsch. Bot. Ges. 74:305. 1961.

Ascospores 2-celled, $16-31 \times 6.5-11 \mu$, hyaline, ellipsoidal to fusiform-ellipsoidal, 1 or 2 guttules per cell, may be constricted at septum; provided at each end with a terminal or subterminal, gelatinous, hooked, curved, or straight appendage; appendage may be caplike or rounded at first, later becoming tapered.

In Typha, reeds, driftwood, and other cellulosic material.

Halosphaeria maritima (Linder) Kohlm.

Can. J. Bot. 50:1956. 1972.

Syn. Remispora maritima Linder.

Farlowia 1:410. 1944.

Ascospores 2-celled, 16-35 $\times 8.5$-15 $\mu$, hyaline, ovoid, ellipsoidal or elongate, 1 large guttule per cell, may be constricted at septum; provided at each end with a mustache-shaped, or pair of stout, tapering, gelatinous appendages.

In driftwood and other cellulosic material.

\section{Halosphaeria mediosetigera Cribb \& Cribb}

Pap. Univ. Queensland Dep. Bot. 3:100. 1956.

Ascospores 2-celled, 24-44.5 $\times 8$-20 $\mu$, hyaline, fusiformellipsoidal or ellipsoidal, ends rounded, may be slight. ly constricted at septum, one or more guttules per cell; provided at each end with a small cap-shaped or cupshaped gelatinous appendage which may become free; in addition, with 3 or 4 crescent-shaped, rigid, equatorial appendages attached laterally along the septum.

In driftwood and other cellulosic material.

Halosphaeria pilleata (Kohlm.) Kohlm.

Can. J. Bot. 50:1957. 1972.

Syn. Remispora pilleata Kohlm.

Nova Hedwigia 6:319. 1963.

Ascospores 2-celled, 24-36.5 $\times 12.5-19 \mu$, hyaline, rhomboidal or diamond-shaped, thick-walled, usually 1 guttule per cell; provided at each end with a gelatinous, pleomorphic, veillike or sheathlike appendage.

In driftwood. 
Halewharia quadricomuta Cribb \& Cribb

Yap. Lnis. Queensland 1)ep. Bot. 3:99. 1956.

Ascospores 2 -celled. $20-36 \times 6-11.5 \mu$. hyaline, ellipsoidal. fusiform-ellipsoidal or elongate, one to several gutsules per cell, may be constricted at septum. occasionally covered by a gelatinous sheath; provided at each end with a pair of acuminate. rigid, occasionally subterminal appendages directed either parallel or at right angles to each other, to $37 \mu$ long.

In driftwod and other cellulosic material. Uncommon in colder waters.

Halw:phacria quadriremis (Höhnk) Kohlm.

Can. J. Bot. 50:1957. 1972.

Sinl. Remispora quadri-remis (Höhnk) Kohlm.

Nova Hedwigia 2:332. 1960.

Ascospores 2-celled. 18-34 $\times 8$ - $15.5 \mu$, hyaline, ellipsoidal to oroid, ends rounded, 1 or 2 large guttules per cell, may be constricted at septum; provided at each end with $4-6$ gelatinous, attenuate, semirigid, tapering appendages, to $35 \mu$ long.

In driftwood and other cellulosic material.

Halosphaeria salina (Meyers) Kohlm.

Can. J. Bot. 50:1957. 1972.

Syn. Remispora salina (Meyers) Kohlm.

Mycologia 60:262. 1968.

Ascospores 2-celled, 19-28 $\times$ 8-13.5 $\mu$, hyaline, ellipsoidal to oblong-ellipsoidal, ends rounded, may be slightly constricted at septum, usually 1 large guttule per cell; provided at each end with 3 or 4 (occasionally 5), terminal or subterminal, radiating, curved or straight, tapering, more or less bulbous appendages to $20 \mu$ long.

In driftwood and other cellulosic material. Less common in colder waters.

Halosphaeria torquata Kohlm.

Nova Hedwigia 2:311. 1960.

Ascospores 2-celled, 20-30.5 $\times 10-16 \mu$, hyaline, broadly ellipsoidal, 1 large guttule per cell, may be constricted at septum; provided at each end with a gelatinous, tapering. semirigid appendage to $15 \mu$ long; in addifion. with an equatorial cylindrical annulus around the septum.

In driftwond and other cellulosic material.

Halssphaeria trullifera (Kohlm.) Kohlm.

Can. J. Bot. 50:1957. 1972.

Syn. Remispora trullifera Kohlm.

Nova Hedwigia 6:321. 1963.

Ascosprores 2-celled, 23-35 $\times 14-20 \mu$, hyaline, ellipsoidal tr) roblong-ellipsoidal, ends rounded, 1 large guttule per cell. may be constricted at septum; provided at each end with a gelatinous slightly tapering or blunt, scooplike ror caplike appendage, to $10 \mu$ wide.

In elriftword.

Koisstoriolla blepharospora J. \& E. Kohlm.

Drsia Hedwigia 9:97. 1965.
Ascospores 2-celled, $12-21 \times 6-8 \mu$. hyaline, ellipsoidal, ends rounded, one to several guttules per cell, may be constricted at septum; provided at one end with 4-7 terminal, radiating, stiff or bristlelike appendages to $13 \mu$ long.

Known only from bark of Rhizophora. Collected on drift floating northward.

\section{Lentescospora submarina Linder}

Farlowia 1:411. 1944.

Ascospores 2-celled (may become 3-celled prior to germination), thick-walled, $15.5-35 \times 6-15 \mu$, hyaline, ellipsoidal or elongate-ellipsoidal, occasionally each cell with a large guttule, may be slightly constricted at septum; provided at each end, only rarely at a single end, with a short, gelatinous appendage, to $7 \mu$ in diameter.

In driftwood and other cellulosic material.

Leptosphaeria albopunctata (West.) Sacc.

Sylloge Fungorum 2:72. 1883.

Ascospores 6- to 8-celled, antepenultimate cell largest, $26-55 \times 10-15 \mu$, light yellow to yellow-brown, fusiform, to broadly fusiform, ends rounded, slightly constricted at septa, curved or straight.

Ascocarp a pseudothecium; asci bitunicate.

In Juncus, Spartina, reeds, driftwood, and other cellulosic material.

\section{Leptosphaeria australiensis (Cribb \& Cribb) Hughes}

Syesis 2:132. 1968 .

Ascospores 4-celled, penultimate cell usually largest, 19$27 \times 5.5-9 \mu$, hyaline, fusiform to ellipsoidal, 1 guttule per cell, constricted at septa.

Ascocarp a pseudothecium; asci bitunicate.

In floating drift of Rhizophora, Avicennia, driftwood, and other cellulosic material. Less common in colder waters.

Leptosphaeria contecta Kohlm.

Nova Hedwigia 6:314. 1963.

Ascospores 4- to 5-celled, penultimate cell usually largest, $32.5-44 \times 8.5-11.5 \mu$, hyaline, fusiform to fusiformellipsoidal, straight or curved, cells guttulate, constricted at septa, covered by a gelatinous, hyaline sheath 9-11 $\mu$ thick.

Ascocarp a pseudothecium; asci bitunicate.

In driftwood, reeds, and other cellulosic material.

\section{Leptosphaeria discors Saccardo \& Ellis in Saccardo} Michelia 2:567. 1882.

Ascospores 4-celled, $28-36 \times 8-14 \mu$, broadly fusoid or broadly ellipsoidal, straight or curved, end cells rounded and hyaline, midcells yellow-brown or brown and each containing a large guttule, constricted at septa.

Ascocarp a pseudothecium; asci bitunicate.

In Juncus, Spartina, floating culms, reeds, driftwood, and other cellulosic material.

Leptosphaeria halima Johnson

Mycologia 48:502. 1956. 
Ascospores 4-celled, penultimate cell largest, $12-18 \times 5$ $8 \mu$, yellow-brown, straight or curved, fusiform or cylindrical, constricted at septa, enclosed in a hyaline, gelatinous sheath 11-17 $\mu$ thick.

Ascocarp a pseudothecium; asci bitunicate.

In Spartina, reeds, driftwood, and other cellulosic material.

Leptosphaeria marina Ellis \& Ever.

J. Mycol. 1:43. 1885.

Ascospores 2- to 4-celled, 48-72 $\times 10-14 \mu$, yellow to yellow-brown, fusiform or elongate-ellipsoidal, ends rounded, straight or curved, constricted at septa.

Ascocarp a pseudothecium; asci bitunicate.

In Juncus, Spartina, reeds, driftwood, and other cellulosic material.

Leptosphaeria maritima (Cooke \& Plow.) Sacc.

Sylloge Fungorum 2:73. 1883.

Ascospores 4 - to 6 -celled, $30-45 \times 6$-14 $\mu$, yellow to yellow-brown, fusiform or ellipsoidal, straight or slightly curved, constricted at septa, conspicuously at midseptum; midcells of unequal size; covered by a thin gelatinous sheath.

Ascocarp a pseudothecium; asci bitunicate.

In Juncus, Spartina, reeds, driftwood, and other cellulosic material.

\section{Leptosphaeria oraemaris Linder}

Farlowia 1:413. 1944.

Ascospores 2- to 4-celled, 17-32 $\times 4-8 \mu$, brown or dark brown, fusoid or ellipsoidal, straight or curved, constricted at septa.

Ascocarp a pseudothecium; asci bitunicate.

In Spartina, reeds, floating culms, driftwood, and other cellulosic material.

\section{Lignincola laevis Höhnk}

Veröff. Inst. Meeresforsch. Bremerhaven 3:216. 1955.

Ascospores 2-celled, 14-24 $\times 5.5-9 \mu$, hyaline, fusiform or ellipsoidal-oblong, straight or slightly curved, 1 large guttule per cell, constricted at septum.

In driftwood and other cellulosic material.

\section{Lindra inflata Wilson}

Trans. Br. Mycol. Soc. 39:411. 1956.

Ascospores multiseptate, 28- to 52-celled, septa narrowly spaced, $210-415 \times 4-6 \mu$, filiform, hyaline, diameter uniform throughout, multiguttulate; provided at each end with a short, clavate or subglobose, hyaline, gelatinous appendage.

In reeds, driftwood, and other cellulosic material.

Lindra thalassiae Orpurt, Meyers, Boral, \& Sims

Bull. Mar. Sci. Gulf Caribb. 14:406. 1964.

Ascospores multiseptate, 15 - to 19-celled, $230-390 \times 3$ $6 \mu$, filiform, curved, s-shaped or u-shaped, hyaline, attenuate, tips slightly inflated.

In Thalassia and Sargassum.
Lulworthia medusa (Ell. \& Ever.) Cribb \& Cribb emend. Cavaliere \& Johnson

Nova Hedwigia 10:434-435. 1966.

Ascospores single-celled, 60-760 $\mu$, hyaline, filiform, tapering, curved, s-shaped, u-shaped or 9 -shaped; provided at each end with a hyaline, tapering, conoid end chamber or appendage of variable length.

Lulworthia medusa-small spore variety "fucicola-type" $60-150 \mu$.

Lulworthia medusa-medium spore variety "medusatype" $230-500 \mu$.

Lulworthia medusa-large spore variety "grandisporatype" $500-760 \mu$.

In Spartina, Typha, Zostera, Fucus, stems of various phanerogams, driftwood, reeds, and other cellulosic material.

\section{Marinospora calyptrata (Kohlm.) Cavaliere}

Nova Hedwigia 11:548. 1966.

Ascospores 2-celled, 22-35 × 9-11 $\mu$, hyaline, ellipsoidal, ends rounded, 1 large guttule per cell, constricted at septum; provided with an appendage at each end, and 3 or 4 of them around the septum, each up to $30 \mu$ in length, hyaline, gelatinous, straight or curved, and terminated with a small involuted cap or tip.

Ascocarp a stromatic structure with unitunicate asci.

In driftwood, reeds, and other cellulosic material.

Massariella maritima Johnson

Mycologia 48:846. 1956.

Ascospores 2-celled, 10-15 $\times 5$-10 $\mu$, yellow-brown, ellipsoidal or oblong-ellipsoidal, 1 large guttule per cell, constricted at septum, surrounded by a relatively thin gelatinous sheath.

In driftwood. Rare.

Microthelia linderi Kohlm.

Trans. Br. Mycol. Soc. 57:483-484. 1971.

Syn. Microthelia maritima (Linder) Kohlm.

Nova Hedwigia 2:322. 1960.

Ascospores 2-celled, $13.5-21 \times 5-7.5 \mu$, brown or light brown, ellipsoidal, clavate or fusiform-ellipsoidal, occasionally curved, one cell usually larger than the other, cells may be minutely guttulate, constricted at septum.

Ascocarp a pseudothecium with bitunicate asci.

In driftwood, culms, and other cellulosic material.

Mycosphaerella ascophylli Cotton

Trans. Br. Mycol. Soc. 3:96. 1908.

Ascospores 2-celled, 15-25 $\times$ 4-6.5 $\mu$, hyaline, fusiform to oblong, ends tapering, guttulate, may be slightly constricted at septum.

Ascocarp a pseudothecium with bitunicate asci.

In Ascophyllum.

Nais inornata Kohlm.

Nova Hedwigia 4:409. 1962.

Ascospores 2-celled, 22-30 × 11.5-15.5 $\mu$, hyaline, broadly ellipsoidal or broadly oval, ends rounded, one large 
and several small guttules per cell, may be slightly constricted at septum.

In driftwood.

Phycomelaina laminariae (Rost.) Kohlm.

Phvitopathol. Z. 63:350-356. 1968.

Ascospores 2-celled, $17.5-27.5 \times 5.5-8 \mu$, hyaline, fusiform-ellipsoidal or ellipsoidal-cylindrical, straight or slightly curved, usually 1 large guttule per cell, constricted at septum; provided at each end with a caplike or globose, elongate or attenuate, gelatinous, more or less polymorphic appendage to $30 \mu$ long.

Ascocarp a stromatic structure with unitunicate asci.

In Laminaria.

Pleospora pelagica Johnson

Mycologia 48:504. 1956.

Ascospores muriform, 7-9 transverse septa, 0-8 longitudinal septa, 35-52 × 9-15 $\mu$, yellow-brown, fusiform, ellipsoidal or clavate-ellipsoidal, usually inequilateral, ends broadly rounded, constricted at midseptum as well as at most others.

Ascocarp a pseudothecium with bitunicate asci.

In Spartina, driftwood, and other cellulosic material.

Pleospora pelvetiae Sutherland

New Phytol. 14:41. 1915.

Ascospores muriform, 3-7 (predominantly 7) transverse septations, several longitudinal ones, $20-35 \times 7-12 \mu$, yellow-brown, ellipsoidal or elongate, ends rounded, constricted at septa.

In various floating culms, reeds, and algae. Uncommon.

\section{Sphaerulina oraemaris Linder}

Farlowia 1:413. 1944.

Ascospores 4-celled, 26-36 $\times$ 5-7 $\mu$, hyaline, fusoid, ends broadly rounded, may be slightly constricted at septa.

In Spartina, various culms, driftwood, and other cellulosic material.

\section{Sphaerulina pedicellata Johnson}

Mycologia 48:846. 1956.

Ascospores 4- to 6 -celled, $36-54 \times 6-15 \mu$, hyaline, elongate-ovoid to elongate-pyriform, one end cell attenuate and curved; may be slightly constricted at septa, usually densely guttulate.

In Spartina, various culms, driftwood, and other cellulosic material.

\section{Torpedospora radiata Meyers}

Mycologia 49:496. 1957.

Ascospores 4- or 5-celled, 30-52 × 4-9 $\mu$, hyaline, oblong or elongate-clavate or cylindrical, usually 2 guttules per cell, slightly constricted at septa; provided at one end with 3 or 4 slender, acuminate, semirigid, radiating appendages to $40 \mu$ long.

In driftword.

Trailia ascophylli Sutherland

Trans. Br. Mycol. Soc. 5:149-151. 1915.
Ascospores long, filamentous and tapering, 90-100 $\times 4$ at the widest diameter, to $1 \mu$ at the narrowest portion, 2- to 4-celled; septations restricted to broad area of spore, narrow area nonseptate, long and attenuate, occasionally' bent or coiled.

In Ascophyllum and Fucus.

\section{Phylum EUMYCOPHYTA}

\section{Class DEUTEROMYCETES}

\section{Alternaria maritima Sutherland}

New Phytol. 15:46. 1916.

Conidia muriform, pyriform; apical cell often attenuate, $14-80 \times 8-18 \mu$, dark brown except for hyaline or pale, attenuate apical cell, constricted at septa, catenulate or simple, smooth or verrucose

Conidiophores simple, erect, short.

In Laminaria, Juncus, Spartina, driftwood, and other cellulosic material.

\section{Arthrobotrys superba Corda}

Pracht-Flora Euro. Schimmel. p. 43. 1839.

Conidia 2-celled,broadly ellipsoidal, ovoid, or slightly pyriform, upper cell usually larger than lower one, 16$23 \times 7-9.5 \mu$; hyaline, slightly constricted at septum.

Conidiophores scattered, bearing 4-10 conidia on slightly expanded tips or short, peglike teeth or denticles.

In driftwood.

Asteromyces cruciatus F. and Mme. Moreau ex Hennebert

Can. J. Bot. 40:1213. 1962.

Conidia single-celled, rarely 2-celled, ellipsoidal, ovoid or broadly pyriform, $9-20 \times 4-9 \mu$ fuscous.

Conidiophores basidialike, hyphae radiate from a bulbous base, bearing 1-13 conidia.

Spores collected in foam.

\section{Botryophialophora marina Linder}

Farlowia 1:404. 1944.

Conidia single-celled, globose or subglobose, $2-3 \mu$ in diameter, hyaline or light, in dense, cottonlike clusters.

Conidiophores (phialides) arising from a subglobose, basal cell, $3-20$ in number, $3.5-8.5 \times 1.5-2.5 \mu$,simple or vase-shaped.

In driftwood and other cellulosic material.

\section{Camarosporium metableticum Trail}

Scott. Nat. 8:267. 1886.

Conidia muriform, broadly ellipsoidal, ends tapering or round, $27-40 \times 11-16 \mu$, fuscous or yellow-brown, 3-9 transverse septa, constricted at septa, apical cells lighter; provided at each end with a gelatinous, caplike or subglobose appendage.

Conidiophores cylindrical, simple, $5-10 \mu$ long, bearing single conidia.

Pycnidia 150-216 $\times 210-330 \mu$, subglobose, solitary, black, innate.

In Ammophila. 
Cirrenalia macrocephala (Kohlm.) Meyers \& Moore

Am. J. Bot. 47:346. 1960.

Conidia 3- to 9-celled, recurved, bent, rarely straight, 10$41 \times 18-28 \mu$; basal cells smaller and hyaline or light, terminal cells larger and fuscous to brown; conspicuously constricted at septa; terminal cell largest, $5-15 \mu$ in diameter.

Conidiophores simple, short, to 3 septate, hyaline or pale yellow, bearing single conidia.

In driftwood and other cellulosic material.

\section{Cladosporium algarum Sutherland}

New Phytol. 15:37. 1916.

Conidia 1- or 2-celled, subglobose, oblong or slightly ellipsoidal, smooth, $5-15 \times 5-10 \mu$, pale olive to brown, constricted at septum.

Conidiophores erect, branched, ends truncate or rounded, septate, olive to brown.

In Laminaria, driftwood, and other cellulosic material.

\section{Clavariopsis bulbosa Anastasiou}

Mycologia 53:11. 1961.

Conidia staurosporous, irregular, 3- or 4-armed, septate, $20-70 \times 6-8.5 \mu$; basal cell brownish; ellipsoidal or ovoid; central cell slightly branched, arms divergent, cylindrical.

Conidiophores long, cylindrical, hyaline, septate, simple or branched.

In driftwood and other cellulosic material.

\section{Clavatospora stellatacula Kirk}

Mycologia 61:178-181. 1969.

Conidia single-celled, staurosporous, triangular, 5-7 $\times$ $6-7 \mu ; 4$ or 5 subapical projections to $2.5 \mu$ long; hyaline.

Conidiophores simple, may be slightly branched; phialides with a collarlike rim.

In driftwood and other cellulosic material.

\section{Cremasteria cymatilis Meyers \& Moore}

Am. J. Bot. 47:348. 1960.

Conidia single-celled, subglobose to ellipsoidal, 7.5-27 $\times 7.5-16 \mu$, rusty brown to light brown, forming chains (catenulate) 2-20 conidia in length; chain strongly constricted at each cell; cells increasing in diameter from base to apex.

Conidiophores short, lateral, single or branched.

In driftwood and other cellulosic materials.

\section{Dendryphiella arenaria Nicot}

Rev. Mycol. 23:93. 1958.

Conidia 2- to 4-celled, ovoid to ellipsoidal, oblong, or slightly cylindrical, $9-20 \times 3.5-6 \mu$, brown, smooth or slightly echinulate, may be slightly constricted at septa; conidial epispore thickened and forms a conspicuous annulus or knot at its point of attachment to the conidiophore.

Conidiophores simple or branched, septate, apical cell slightly inflated, light brown to subhyaline, $15-90 \mu$ long.
In Sargassum, floating Thalassia, Ammophila, driftwood, and other cellulosic material.

Dendryphiella salina (Suth.) Pugh \& Nicot

Trans. Br. Mycol. Soc. 47:226. 1944.

Conidia 2- to 12-celled (predominantly 4- to 6-celled), elongate, cylindrical or fusiform-ellipsoidal, straight or curved, ends rounded or tapered, 14.5-75 × 5.5-10.5 $\mu$, light brown or olive, may be slightly constricted at septa; solitary or catenulate; epispore of conidia thickened at point of attachment to the conidiophore.

Conidiophores simple or branched, septate, apical cell slightly inflated, light brown to yellowish.

In Chondrus, Laminaria, Spartina.

Dictyosporium pelagicum (Linder) G. C. Hughes ex Johnson \& Sparrow

Fungi in Oceans and Estuaries, p. 391-392. 1961.

Conidia muriform; form variable, ovoid, clavate, branched (boxing-glovelike), irregular; several branches may arise from a single basal cell; 12 $66 \times 10-35 \mu$, dark brown, occasionally black; conspicuously constricted at septa.

Conidiophores simple, pale brown or dark brown, septate, $15-35 \times 1-2.5 \mu$.

In driftwood and other cellulosic material.

Diplodia oraemaris Linder

Farlowia 1:403. 1944.

Conidia 2-celled (rarely single-celled), ovoid or ellipsoidal 6-11 $\times 3.5-7.5 \mu$, yellow-brown, may be slightly constricted at septum.

Conidiophores simple, single-celled, hyaline.

Pycnidia 135-365 × 140-470 $\mu$, flattened, black above, cream to hyaline below.

In driftwood and other cellulosic material.

Humicola alopallonella Meyers \& Moore.

Am. J. Bot. 47:346. 1960.

Conidia 1- or 2-celled (occasionally 3-celled), obpyriform to clavate, $8-17.5 \times 15-37.5 \mu$ apical cell largest and brownish, basal cell small and yellow to hyaline, constricted at septum.

Conidiophores one to several celled, simple, hyaline to light fuscous.

In driftwood and other cellulosic material.

Macrophoma (Saccardo) Berlese \& Voglio

Sylloge Fungorum 1-4:306. 1886.

Conidia single-celled, ovate to elongate, over $15 \mu$ long, hyaline or subhyaline.

Conidiophores simple, short, filiform.

Pycnidia innate, erumpent, lenticular or subglobose.

In driftwood and other cellulosic material.

Monodictys pelagica (Johnson) Jones

Trans. Br. Mycol. Soc. 46:138. 1963.

Conidia muriform, ovoid or spherical, more commonly obpyriform, symmetrical or asymmetrical, 15$44 \times 12.5-37 \mu ; 1-3$ brown or yellowish basal cells, 
brownish or blackish terminal cells, or concolorous black throughout: may be conspicuously constricted at septa. Conidiophores dark fuscous, septate, 1- to 3celled. simple.

In driftwood and other cellulosic material.

\section{Orbimyces spectabilis Linder}

Farlowia 1:404. 1944.

Conidia staurosporous, multicellular; basal cell globose to subglobose, shining black, $22-42 \mu$ in diameter; provided with one or two sets of radiating, fingerlike, septate filaments to $6 \mu$ wide and to $50 \mu$ long; each set of radiating filaments join a common dark basal cell; radiating cells may lighten in color from base to apex.

In driftwood and other cellulosic material.

\section{Papulospora halima Anastasiou}

Nova Hedwigia 6:266. 1963.

Hy phae septate, hyaline or brown, anastomosing, to $4.8 \mu$ in diameter, with hyphal thickenings, chainlike; large masses of hyphae or bulbils formed, subglobose, compact, to $870 \mu$ in diameter, dark brown or black.

No spores formed.

In driftwood and other cellulosic material.

Periconia prolifica Anastasiou

Nova Hedwigia 6:260. 1963.

Conidia single-celled, globose to subglobose, $6-20 \mu$ in diameter, light brown to brown, light red to rust, thickwalled, smooth, catenulate.

Conidiophores hyaline, septate, simple or branched, to $200 \mu$ long.

In driftwood and other cellulosic material.

\section{Phialophorophoma litoralis Linder}

Farlowia 1:403. 1944.

Conidia single-celled, hyaline, ellipsoidal or pyriform, 2.5-4.5 $\times 1.5-2 \mu$, endogenous.

Conidiophores (phialides) simple or branched, nonseptate, hyaline, bottle-shaped, with a collarlike, flaring neck.

Pycnidia innate, ovoid or ellipsoidal, 110-175 $\mu$.

In driftwood and other cellulosic material.

\section{Phoma Saccardo}

Michelia 2:4. 1880.

Conidia single-celled, ellopsoidal or bacilliform, hyaline, $1.5-7.5 \mu$.

Pycnidia innate, ellipsoidal or subglobose.

In Laminaria, Spartina, Juncus, various reeds, driftwond, and other cellulosic material.

Stemphylium maritimum Johnson

Mycologia 48:844. 1956.

Conidia muriform, ellipsoidal, globose, pyrimidal, or irregular, $19-32 \times 17-29 \mu$, dark brown, smooth or verrucose, constricted at septa.

Conidiophores simple, apiculate.

In driftwond and other cellulosic material.
Trichocladium achrasporum (Meyers \& Moore) Dixon Mycologia 63:237. 1971.

Syn. Culcitalna achraspora Meyers \& Moore

Am. J. Bot. 47:349. 1960.

Conidia 3- to 6-celled, clavate, ovate, or broadly obpyriform, $15-45 \times 8-24 \mu$; cells increase in size and darken from base to apex, terminal cells dark brown; dark cells guttulate; constricted at septa.

Conidiophores simple, short or long, septate, hyaline, pale yellor or brownish, straight or curved.

In driftwood and other cellulosic material.

Varicosporina ramulosa Meyers \& Kohlm.

Can. J. Bot. 43:916. 1965.

Conidia staurosporous, cylindrical, multiseptate, several radiating arms usually at right angles to each other, hyaline; most commonly seen as 3 radiating, multicellular, cylindrical hyphal strands to $45 \mu$ long.

In Sargassum, Thalassia, and Typha. Absent in colder waters north of New Jersey.

\section{Zalerion maritimum (Linder) Anastasiou}

Can. J. Bot. 41:1136. 1963.

Conidia helicosporous, 1-3 times coiled, multiseptate, all cells approximately similar in size, to 14 cells long, occasionally longer, deeply constricted at septa, to $12 \mu$ in diameter, fuscous to black.

Conidiophores simple or once-branched, hyaline, yellow, or pale fuscous, septate.

In driftwood and other cellulosic material.

\section{Zalerion varium Anastasiou}

Can. J. Bot. 41:1136. 1963.

Conidia helicosporous, coiled in 3 planes, single or hranched; cells 5.5-13 $\times 4.5-10.5 \mu$, dark brown to black; clusters to $65 \mu$ in diameter, occasionally grapelike clusters.

Conidia simple, fuscous to black.

In driftwood and other cellulosic material.

\section{Phylum EUMYCOPHYTA}

\section{Class BASIDIOMYCETES}

\section{Nia vibrissa Moore \& Meyers}

Mycologia 51:874. 1959.

Basidiospores single-celled, ovoid to ellipsoidal, or broadly ellipsoidal, $7.5-15 \times 6.5-15 \mu$, hyaline; provided at one end with a single, gelatinous, filiform appendage to $50 \mu$ long, and 3-5 additional ones similar in shape but slightly shorter at the opposite end.

Basidiocarp orange to orange-brown.

In Spartina, driftwood, and other cellulosic material.

\section{SELECTED BIBLIOGRAPHY}

AINSWORTH, G.C.

1971. Ainsworth \& Bisby's dictionary of the fungi. 6th ed. Commonw. Mycol. Inst., Kew, Surrey, Engl., 663 p. 
BARGHOORN, E. S., and D. H. LINDER.

1944. Marine fungi: Their taxonomy and biology. Farlowia $1: 395-467$

CAVALIERE, A. R.

1966. Marine Ascomycetes: Ascocarp morphology and its application to taxonomy. I. Nova Hedwigia 10:387-398.

1973. Ascomycetes. In Peter Gray (editor), Encyclopedia of microscopy and microtechnique, $638 \mathrm{p}$. Van Nostrand Reinhold Co.

CAVALIERE, A. R., and T. W. JOHNSON, JR.

1966. Marine Ascomycetes: Ascocarp morphology and its application to taxonomy. II-V. Nova Hedwigia 10:399-461.

HUGHES, G. C.

1975. Studies of fungi in oceans and estuaries since 1961. I. Lignicolous, caulicolous and foliicolous species. Oceanogr. Mar. Biol. Ann. Rev. 13:69-180.
JOHNSON, T. W., JR., and F. K. SPARROW, JR.

1961. Fungi in oceans and estuaries. J. Cramer Weinheim, 668 p.

KIRK, P. W., Jr.

1969. Isolation and culture of lignicolous marine fungi. Mycologia 61:174-177.

KOHLMEYER, J.

1972. A revision of Halosphaeriacaea. Can. J. Bot. 50:19511963.

KOHLMEYER, J., and E. KOHLMEYER.

1971. Synoptic plates of higher marine fungi. 3rd ed. Lehre Cramer, $87 \mathrm{p}$.

SNELL, W. H., and E. A. DICK.

1957. A glossary of mycology. Harvard Univ. Press, Cambridge, Mass., 171 p. 


\section{INDEX OF GENERA AND SPECIES OF MARINE FUNGI}

Alternaria maritima

37,44

Amylocarpus encephaloides . . . . . . . . 14, 39

Arthrobotrs superba ............ 34, 44

Asteromyces cruciatus . . . . . . . . . 34, 44

Botriophialophora marina ......... 34, 44

Camarosporium metableticum . . . . . . . . 32, 44

Carbospaerella leptosphaerioides . . . . . . 28, 39

Ceriosporopsis .............. 19, 20, 21

cambrensis . .............. 21, 39

halima ................ 21, 40

tubulifera ...............21,40

Chaetosphaeria chaetosa ......... 27,40

Cirrenalia macrocephala . . . . . . . . 38, 45

Cladosporium algarum ........... 34, 45

Clatariopsis bulbosa ........... 36, 45

Clatatospora stellatacula . . . . . . . . 35, 45

Corollospora ............. 19, 20, 22, 27

comata ................ 23,40

cristata ............... 23, 40

lacera ................. 22, 40

maritima ............. 22, 40

trifurcata ................ 22, 40

Cremasteria cymatilis . . . . . . . . 35, 45

Culcitalna ............... . 46

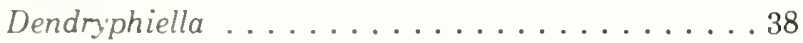

arenaria ............... 38, 45

salina . . . . . . . . . . . . . 39, 45

Dictyosporium pelagicum ... . . . . . 37, 45

Didymella fucicola . . . . . . . . . . . . 16, 40

Didymosamarospora euryhalina . . . . . . . 18, 40

Didymosphaeria .............. 17, 23

danica . . . . . . . . . . . . . 23, 40

enalia ................. 23, 41

Diplodia oraemaris . . . . . . . . . 33, 45

Haligena . . . . . . . . . . . . . 13, 28, 29

elaterophora . . . . . . . . . . . 29, 41

viscidula ................ 29,41

Haloguignardia ... . . . . . . . . . 15

oceanica . . .............. 15,41

tumefaciens .............. 15, 41

Halonectria milfordensis . . . . . . . . . 13, 14, 41

Halosphaeria . . . . . . . . . . . 18, 19, 20, 23

appendiculata ............. 24, 41

cucullata ............... 25,41

hamata ............... 25, 41

maritima ............. 26,41

mediosetigera ............... 24, 41

pilleata ................ 25,41

quadricornuta ............ 26, 42

quadriremis .............. 26, 41 salina $\ldots \ldots \ldots \ldots \ldots \ldots \ldots \ldots \ldots, 42$

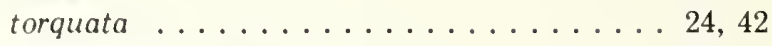

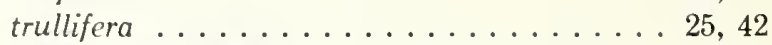

Humicola alopallonella . . . . . . . . . . 35, 45

Keissleriella blepharospora . . . . . . . . . 442

Lentescospora submarina . . . . . . . . . 19, 28, 42

Leptosphaeria . . . . . . . . . . 17, 28, 29

albopunctata ............... 31, 42

australiensis . . . . . . . . . . . 30, 42

contecta ................ 31, 42

discors ............... 30,42

halima ............... 29, 42

marina .............. 30, 43

maritima ............. 31,43

oraemaris . ............. . 30, 43

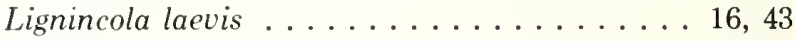

Lindra . . . . . . . . . . . . . . 13, 14

inflata ............... 14, 43

thalassiae .............14, 43

Lulworthia medusa . . . . . . . . . . . 12, 43

Macrophoma ............... 33, 45

Marinospora calyptrata . . . . . . . . 20,43

Massariella maritima . . . . . . . . . 18, 43

Microthelia linderi . . . . . . . . . . . 17, 43

Monodictys pelagica .......... . 37, 45

Mycosphaerella ascophylli . . . . . . . . . 16, 43

Nais inornata . . . . . . . . . . . . 17, 43

Nia vibrissa . . . . . . . . . . . 11, 46

Orbimyces spectabilis . . . . . . . . . . 36, 46

Papulospora halima ... . . . . . . 32, 46

Periconia prolifica . . . . . . . . . . 35, 46

Phialophorophoma litoralis . . . . . . . . 32, 46

Phoma . . . . . . . . . . . . . . 33, 46

Phycomelaina laminariae . . . . . . . . 20, 44

Phyllachorella .................41

Pleospora .................... . 15

pelagica .............. 15, 44

pelvetiae .............. 15, 44

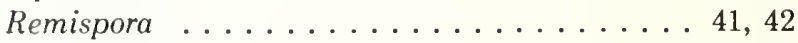

Sphaerulina ............... 28, 31

oraemaris .............. 31, 44

pedicellata .............. . 31, 44

Stemphylium maritimum . . . . . . . . . 37, 46

Torpedospora radiata . . . . . . . . . . 27, 44

Trailia ascophylli . . . . . . . . . . . 13, 44

Trichocladium achrasporum ........ . 38, 46

Varicosporina ramulosa . . . . . . . . . 36, 46

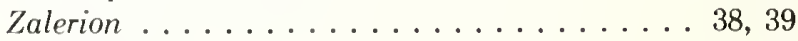

maritimum ............. 39, 46

varium . . . . . . . . . . . 39, 46 


\section{ACKNOWLEDGMENTS}

Preparation of the "Marine Flora and Fauna of the Northeastcrn United States" is being coordinated by the following Board:

\section{Coordinating Editor:}

Melbourne R. Carriker, College of Marine Studies, Marine Studies Center, University of Delaware, Lewes, DE 19958.

Editorial Advisers:

Marie B. Abbott, Marine Biological Laboratory, Woods Hole, Mass.

Arthur G. Humes, Boston University Marine Program, Marine Biological Laboratory, Woods Hole, Mass.

Wesley N. Tiffney, Department of Biology, Boston University, Boston, Mass.

Ruth D. Turner, Museum of Comparative Zoology, Harvard University, Cambridge, Mass.

Roland L. Wigley, National Marine Fisheries Service, Northeast Fishery Center, Woods Hole, Mass.

Robert T. Wilce, Department of Botany, University of Massachusetts, Amherst, Mass.

The Board, established the format for the "Marine Flora and Fauna of the Northeastern United States," invites systematists to collaborate in the preparation of manuals, reviews manuscripts, and advises the Scientific Editor of the National Marine Fisheries Service.

Acknowledgment is made to Gettysburg College for generously awarding two Faculty Fellowship Grants in support of this study. In addition, I express appreciation to the staff of the Biological Marine Laboratory, Woods Hole, Mass., and especially the Duke University Marine Laboratory, Beaufort, N.C., where most of this work was accomplished. I am grateful to Jan Kohlmeyer, Institute of Marine Sciences, University of North Carolina, for critically reviewing the manuscript. Acknowledgment is made to my students who spend numerous hours modifying the keys and locating the conspicuous rough spots so common in works of this kind. Finally, I am indebted to my wife, Shirlee, for her many suggestions, her help in organizing several parts of the work, and for typing the manuscript.

Preparation of this manual was supported in part by a grent from the Environmental Protection Agency to the Editsrial Board of the "Marine Flora and Fauna of the Northeastern United States." Work on the "Marine Flora and Fauna of the Northeastern United States" by the Coordinating Editor is supported by the College of Marine Studies, University of Delaware.

\section{COORDINATING EDITOR'S COMMENTS}

Publication of the "Marine Flora and Fauna of the Northeastern United States" is most timely in view of the growing universal emphasis on environmental work and the urgent need for more precise and complete identification of coastal organisms than has been available. It is mandatory, wherever possible, that organisms be identified accurately to species. Accurate scientific names unlock the great quantities of biological information stored in libraries, obviate duplication of research already done, and make possible prediction of attributes of organisms that have been inadequately studied.
A. R. Cavaliere began his studies on the taxonomy and morphology of marine Ascomycetes in 1961 as a graduate student at Duke University. Since that time his work has expanded to include the occurrence and systematics of marine fungi along selected areas of the Pacific and Atlantic coasts of the United States, as well as Nova Scotia and Iceland.

Manuals are available for purchase from the Superintendent of Documents, U.S. Government Printing Office, Washington, D.C. 20402. The manuals so far published on the series are listed below.

COOK, DAVID G., and RALPH O. BRINKHURST. Marine flora and fauna of the Northeastern United States. Annelida:

Oligochaeta.

BORROR, ARTHUR C. Marine flora and fauna of the Northeastern United States. Protozoa: Ciliophora.

MOUL, EDWIN T. Marine flora and fauna of the Northeastern United States. Higher plants of the marine fringe.

McCLOSKEY, LAWRENCE R. Marine flora and fauna of the Northeastern United States. Pycnogonida.

MANNING, RAYMOND B. Marine flora and fauna of the Northeastern United States. Crustacea: Stomatopoda.

WILLIAMS, AUSTIN B. Marine flora and fauna of the Northeastern United States. Crustacea: Decapoda.

POLLOCK, LELAND W. Marine flora and fauna of the Northeastern United States. Tardigrada.

LARSON, RONALD J. Marine flora and fauna of the Northeastern United States. Cnidaria: Scyphozoa.

CAVALIERE, A. R. Marine Flora and Fauna of the Northeastern United States. Higher Fungi: Ascomycetes, Deuteromycetes, and Basidiomycetes. 

388. Proceedings of the first U.S.-Japan meeting on aquaculture at Tokyo, Japan, October 18-19, 1971. William N. Shaw (editor). (18 papers, 14 authors.) February 1974, iii +133 p. For sale by the Superintendent of Documents, U.S. Government Printing Office, Washington, D.C. 20402.

389. Marine flora and fauna of the northeastern United States. Crustacea: Decapoda. By Austin B. Williams. April 1974, iii + 50 p., 111 figs. For sale by the Superintendent of Documents, U.S. Government Printing Office, Washington, D.C. 20402.

390. Fishery publications, calendar year 1973: Lists and indexes. By Mary Ellen Engett and Lee C. Thorson. September 1974, iv + 14 p., 1 fig. For sale by the Superintendent of Documents, U.S. Government Printing Office, Washington, D.C. 20402.

391. Calanoid copepods of the genera Spinocalanus and Mimocalanus from the central Arctic Ocean, with a review of the Spinocalanidae. By David M. Damkaer. June $1975, x+88$ p., 225 figs., 4 tables. For sale by the Superintendent of Documents, U.S. Government Printing Office. Washington, D.C. 20402.

392. Fishery publications, calendar year 1974: Lists and indexes. By Lee C. Thorson and Mary Ellen Engett. June 1975, iv + 27 p., 1 fig.

393. Cooperative Gulf of Mexico estuarine inventory and study-Texas: Area description. By Richard A. Diener. September 1975, vi + 129 p., 55 figs., 26 tables.

394. Marine Flora and Fauna of the Northeastern United States, Tardigrada. By Leland W. Pollock. May 1976, iii +25 p., figs. For sale by the Superintendent of Documents, U.S. Government Printing Office, Washington. D.C. 20402 .

395. Report of a colloquium on larval fish mortality studies and their relation to fishery research, January 1975. By John R. Hunter. May 1976, iii +5 p. For sale by the Superintendent of Documents, U.S. Government Printing Office, Washington, D.C. 20402. 
PENN STATE UNIVERSITY LIBRARIES

UNITED STATES

DEPARTMENT OF COMMERCE

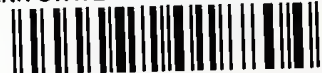

A000072018804

A. SUA. "IAE VE FISMERIES SERVICE

MUSIAGE AND FEES PAID US DEPARTMENT OF COMMERCE con 450

SEt

COM 210

THIRD CLASS

STE CA, BUSINESS

BULK RATE 